\begin{tabular}{|c|c|}
\hline Title & Effect of $\mathrm{Cu}$ on oxidation behaviour of FCC Fe Ni-Cr-Al and $\mathrm{Ni}-\mathrm{Cr}$-Al based alloys \\
\hline Author(s) & Hay ashi, Shigenari; Kudo, Daiki; Nagashima, Ryouta; Utsumi, Haruki \\
\hline Citation & $\begin{array}{l}\text { Corrosion Science, 163, } 108273 \\
\text { https://doi.org/10.1016/.corsci.2019.108273 }\end{array}$ \\
\hline Issue Date & $2020-02$ \\
\hline Doc URL & http:/hdl .handle.net/2115/83983 \\
\hline Rights & $\begin{array}{l}\text { (2020. This manuscript version is made avail able under the CC-BY-NC-ND } 4.0 \text { license } \\
\mathrm{http} / / \text { rereativecommons.org/icenses/by-nc-nd/4.0/ }\end{array}$ \\
\hline Rights(URL) & http://creativecommons.org/icenses/by-nc-nd/4.0/ \\
\hline Type & article (author version) \\
\hline File Information & manuscript revised_final HUSCUP.pdf \\
\hline
\end{tabular}

Instructions for use 


\title{
Effect of Cu on Oxidation Behaviour of FCC Fe-Ni-Cr-Al and Ni-Cr-Al Based
}

\section{Alloys}

\author{
Shigenari Hayashi ${ }^{1}$, Daiki Kudo ${ }^{1}$, Ryouta Nagashima ${ }^{2}$ and Haruki Utsumi ${ }^{1}$ \\ ${ }^{1}$ Division of Material Science and Engineering, Graduate School of Engineering, Hokkaido University, \\ ${ }^{2}$ School of Materials and Chemical Technology, Tokyo Institute of Technology. \\ ${ }^{1}$ Kita13 Nishi8, Kita-ku, Sapporo, Hokkaido 060-8628, Japan \\ 2 2-12-1 Ookayama, Meguro-ku, Tokyo, 152-8552, Japan
}

\begin{abstract}
The high-temperature oxidation behaviour of Fe-Ni-Cr-Al and Ni-Cr-Al alloys with and without $\mathrm{Cu}$ addition was investigated at $1000^{\circ} \mathrm{C}$ in air to determine the effect of $\mathrm{Cu}$ on the critical $\mathrm{Al}$ content necessary for forming an external $\mathrm{Al}_{2} \mathrm{O}_{3}$ scale. The oxidation mass gain of $\mathrm{Fe}-17 \mathrm{Ni}-17 \mathrm{Cr}-$ 7.7 Al-Cu and $\mathrm{Ni}-17 \mathrm{Cr}-10 \mathrm{Al}$ alloys was found to decrease with increased $\mathrm{Cu}$ content. An external $\mathrm{Al}_{2} \mathrm{O}_{3}$ scale developed when $5 \mathrm{at} \% \mathrm{Cu}$ and more and $10 \mathrm{at} \% \mathrm{Cu}$ and more was added to $\mathrm{Fe}-17 \mathrm{Ni}$ 17Cr-7.7Al and $\mathrm{Ni}-17 \mathrm{Cr}-10 \mathrm{Al}$ alloys, respectively. The beneficial effect of $\mathrm{Cu}$ is inferred to be due to decreased oxygen concentration at the alloy surface and enhanced $\mathrm{Al}$ outward diffusion.
\end{abstract}

Keywords: $\mathrm{Al}_{2} \mathrm{O}_{3}$-scale forming austenitic Fe-base alloy, $\mathrm{Cu}$ effect, critical $\mathrm{Al}$ content for $\mathrm{Al}_{2} \mathrm{O}_{3}$ scale formation

\section{INTRODUCTION}

Austenitic heat-resistant steels are expected to have excellent high-temperature mechanical properties at elevated temperatures. Most conventional austenitic heat-resistant steels form a $\mathrm{Cr}_{2} \mathrm{O}_{3}$ scale, which protects the steel in various high-temperature oxidation/corrosion environments. However, the thermal stability of $\mathrm{Cr}_{2} \mathrm{O}_{3}$ is inferior to $\mathrm{Al}_{2} \mathrm{O}_{3}$ in harsh environments when such environments contain aggressive species such as $\mathrm{C}, \mathrm{S}$, and $\mathrm{Cl}_{2}$ at higher temperatures. Thus, using a protective $\mathrm{Al}_{2} \mathrm{O}_{3}$ scale is favoured as a protective oxide scale, because it provides better oxidation resistance in such aggressive environments. However, only ferritic steels and Nibased alloys are available to form an $\mathrm{Al}_{2} \mathrm{O}_{3}$-scale in current heat-resistant alloy systems. For example, Fe-Cr-Al ferritic steels in particular, which form an $\mathrm{Al}_{2} \mathrm{O}_{3}$-scale, have excellent oxidation resistance and are widely used in various high-temperature components such as heating wire and metal foil for catalytic converters. However, in general the mechanical properties of 
ferritic steels at high temperatures are not sufficient to make them for structural components. Thus, the only available alloys that form an $\mathrm{Al}_{2} \mathrm{O}_{3}$ scale that can be used at elevated temperatures higher than $700^{\circ} \mathrm{C}$ are Ni-based alloys. Although Ni-based alloys possess both excellent mechanical properties and oxidation performance, these alloys are much more expensive than other steels. Therefore, there is a need to develop $\mathrm{Al}_{2} \mathrm{O}_{3}$-scale forming austenitic heat resistant steels that can be produced by a conventional low-cost process such as a hot rolling.

$\mathrm{Al}_{2} \mathrm{O}_{3}$-scale forming austenitic steels require higher $\mathrm{Al}$ content for $\mathrm{Al}_{2} \mathrm{O}_{3}$ scale formation. This is because of the smaller diffusivity of solute elements in the fcc matrix. An addition of more than $20 \mathrm{at} \% \mathrm{Al}$ is necessary for $\mathrm{Al}_{2} \mathrm{O}_{3}$ scale to form on $\mathrm{Fe}-20 \% \mathrm{Ni}$ alloy, and the required $\mathrm{Al}$ content increases with increasing $\mathrm{Ni}$ content [1, 2]. However, higher $\mathrm{Al}$ addition to austenitic steels results in the precipitation of bcc $\alpha$-Fe and different compounds containing higher Al content such as a $\beta$-(Fe,Ni)Al and $\gamma^{\prime}-(\mathrm{Ni}, \mathrm{Fe})_{3} \mathrm{Al}$ phases [3]. Due to the formation of $\beta-\mathrm{Fe}(\mathrm{Ni}) \mathrm{Al}$-precipitates, $\mathrm{Al}$ content in the matrix $\gamma$-phase does not increase effectively. Consequently, the oxidation performance of alloys would not be improved as it is expected by the addition of Al with higher concentration. Brady et al. proposed $\mathrm{Al}_{2} \mathrm{O}_{3}$-scale forming austenitic steels that have good creep resistance due to the precipitation of different compounds: $\beta$-(Fe,Ni)Al, Laves-Fe $\mathrm{Fe}_{2}(\mathrm{Mo}, \mathrm{Nb}), \sigma$, and carbides [4,5]. Brady et al. also found these steels have good oxidation resistance due to $\mathrm{Nb}$ addition, which significantly decreases the $\mathrm{Al}$ content by $2.5 \mathrm{wt} \%$ to form an external $\mathrm{Al}_{2} \mathrm{O}_{3}$ scale on austenitic steels [6]. The $\beta$-NiAl-precipitates enhance the creep-resistance of ferritic [7] and austenitic [8] steels. However, as mentioned above, the formation of $\beta$-NiAl-precipitates might decrease the oxidation performance. In addition, manufacturing steels that contain $\beta-\mathrm{Fe}(\mathrm{Ni}) \mathrm{Al}$ precipitates by conventional methods such as a rolling would be difficult. Therefore, decreasing the critical $\mathrm{Al}$ content necessary for formation of an external $\mathrm{Al}_{2} \mathrm{O}_{3}$ scale on austenitic steels is necessary if new $\mathrm{Al}_{2} \mathrm{O}_{3}$-forming austenitic steels are to be developed.

In our preliminary investigation, we found $\mathrm{Cu}$ addition to austenitic steels is beneficial for $\mathrm{Al}_{2} \mathrm{O}_{3}$-scale formation. Moreover, $\mathrm{Cu}$ precipitation in austenitic stainless steels is known to improve high-temperature mechanical properties $[9,10]$. Therefore, $\mathrm{Cu}$ addition to the austenitic substrate is expected to be beneficial for both the mechanical properties and oxidation performance at higher temperatures. In this study, we investigated the oxidation behaviour of Fe$\mathrm{Ni}-\mathrm{Cr}-\mathrm{Al}$ alloys with and without $\mathrm{Cu}$ addition and tried to clarify the effect of $\mathrm{Cu}$ on the development of external $\mathrm{Al}_{2} \mathrm{O}_{3}$ scale. In order to assess the effect of $\mathrm{Cu}$ on oxidation behaviour, oxidation behaviour of simple $\mathrm{Ni}-\mathrm{Cr}-\mathrm{Al}$ alloys with and without $\mathrm{Cu}$ addition was also evaluated. 


\section{EXPERIMENTAL PROCEDURE}

Fe-based fcc matrix Fe-Ni-Cr-Al-Zr and Ni-based Ni-Cr-Al-Zr alloys with and without different $\mathrm{Cu}$ contents were prepared by argon-arc melting using high purity metals (99.99\%). Table 1 shows the nominal composition of the alloys used in this study. Zr was used to prevent spallation of the oxide scale $[11,12]$. All the alloy ingots were homogenized at $1200^{\circ} \mathrm{C}$ for $24 \mathrm{~h}$ in a vacuum, $\sim 5 \times 10^{-3} \mathrm{~Pa}$. Oxidation specimens approximately $1 \mathrm{~mm}$ thick were cut from the homogenized ingots and polished down to a 3- $\mu \mathrm{m}$ diamond paste. Prior to the oxidation experiments the specimens were ultrasonically cleaned in acetone.

The oxidation tests were carried out in a box furnace at $1000^{\circ} \mathrm{C}$ in air. Specimens were placed in individual alumina crucibles in order to collect spalled oxide scale and these crucibles were placed in the furnace hot zone. Specimens were heated to $1000^{\circ} \mathrm{C}$ at a rate of $10^{\circ} \mathrm{C} / \mathrm{min}$ and oxidized for a given time up to $100 \mathrm{~h}$ after furnace temperature reached at $1000^{\circ} \mathrm{C}$ in air. After a given oxidation time, specimens were furnace cooled in air. The mass gain/loss was measured at room temperature with a precision balance, thereafter the specimens were returned to the furnace again at room temperature and oxidized again. With this "pseudo-cyclic" oxidation study, cyclic oxidation kinetics and spallation resistance of the oxide scale were evaluated. The initial oxidation behaviour of alloys, development of oxides during heating at a rate of $50^{\circ} \mathrm{C} / \mathrm{min}$ followed by isothermal oxidation at $1000^{\circ} \mathrm{C}$ in air for $30 \mathrm{~min}$, was performed by an in-situ high-temperature XRD in air by means of synchrotron radiation at the SPring-8 facility in Hyogo, Japan. The detailed experimental condition of in-situ HTXRD is described elsewhere [13]. Internal oxidation of several Ni-based alloys was also conducted at $1000^{\circ} \mathrm{C}$. The samples were sealed in a vacuum quartz capsule with a mixture of $\mathrm{Ni} / \mathrm{NiO}$ powders to avoid formation of $\mathrm{Ni}$ oxide and heated at $1000^{\circ} \mathrm{C}$ for different oxidation times of up to $64 \mathrm{~h}$.

After the oxidation test, cross-sections of the oxide scale were observed by using a scanning electron microscope and the distribution of each element was analysed by using an electron probe micro analyser (EPMA). The oxide scale formed in the very initial oxidation stage was analysed by Glow Discharge Optical Emission Spectroscopy (GD-OES).

\section{RESULTS}

\subsection{Oxidation kinetics of alloys}

\section{$<$ Fe-based alloys $>$}

Figure 1 shows the oxidation kinetics of Fe-based alloys used in this study. The oxidation of all the alloys was initially rapid and then followed by slower oxidation kinetics. The initial oxidation 
mass gain of the alloys without $\mathrm{Cu}$ rapidly increased up to about $20 \mathrm{~h}$ and then transitioned to the slower oxidation stage. This initial oxidation mass gain decreased with increasing $\mathrm{Cu}$ content up to $5 \mathrm{at} \%$. The oxidation rate in the slower oxidation stage also decreased with increasing $\mathrm{Cu}$ content. Compared with the Fe-17Ni-17Cr-7.7Al-5Cu alloy, the initial oxidation mass gain of low $\mathrm{Cr}$ alloy (15at\%) increased, but the rate of oxidation in the slower oxidation stage was slower. The oxidation kinetics of the low $\mathrm{Al}$ alloy, $\mathrm{Fe}-17 \mathrm{Ni}-17 \mathrm{Cr}-6 \mathrm{Al}-5 \mathrm{Cu}$, increased and was similar to that of 7.7Al-3.5Cu alloy. Figure 2 shows the Effect of $\mathrm{Cu}$ content on the oxidation mass gain on a series of Fe-17Ni-17Cr-7.7 Al-Cu alloys after $100 \mathrm{~h}$. In this plot, the oxidation mass gains of 3.8 and $4.3 \mathrm{Cu}$ alloys for $100 \mathrm{~h}$ were obtained by a continuous isothermal oxidation for $100 \mathrm{~h}$. Oxidation behaviour transitioned from less protective to protective behaviour at about $4 \mathrm{at} \% \mathrm{Cu}$ additions.

\section{$<$ Ni-based alloys $>$}

Figure 3 shows the oxidation kinetics of Ni-based alloys. Similar to the oxidation behaviour of Fe-based alloys, initial rapid oxidation was observed for Ni-17Cr-10Al and Ni-17Cr-10Al-5Cu. The rate of oxidation of those alloys decreased after about $30 \mathrm{~h}$ of oxidation. Higher $\mathrm{Cu}$ addition decreased this initial rapid oxidation, and transitioned to the slower oxidation stage in shorter oxidation time. The oxidation rate of alloys with 10 and $15 \mathrm{Cu}$ in the slower oxidation stage after $5 \mathrm{~h}$ of oxidation was similar.

These results indicate that $\mathrm{Cu}$ addition is beneficial, as it decreases the initial oxidation mass gain for both $\mathrm{Fe}$ and Ni-based alloys, which indicate that $\mathrm{Cu}$ addition promotes the external $\mathrm{Al}_{2} \mathrm{O}_{3}$ scale formation. However, higher $\mathrm{Cu}$ addition was necessary for Ni-based alloys for this transition.

\subsection{Cross-sections of oxide scale}

\section{$<$ Fe-based alloys $>$}

Figure 4 shows cross-sections of Fe-17Ni-17Cr-7.7Al-Cu alloys after oxidation for $100 \mathrm{~h}$. A thick duplex oxide scale consisting of an outer Fe oxide scale containing $\mathrm{NiO}$ and an inner $\mathrm{Cr}_{2} \mathrm{O}_{3}$ layers was formed on the alloy without $\mathrm{Cu}$. $\mathrm{Al}$ was oxidized internally to form $\mathrm{Al}_{2} \mathrm{O}_{3}$-precipitates below a $\mathrm{Cr}_{2} \mathrm{O}_{3}$ layer. Internal AlN-precipitate formation was also observed below the internal Al oxidation zone (Fig. 4a, d). An outer Fe-rich oxide scale was also observed on the alloy with $3.5 \mathrm{at} \% \mathrm{Cu}$; however, it was thin and discontinuously distributed on the surface of the $\mathrm{Cr}_{2} \mathrm{O}_{3}$ scale. Internal $\mathrm{Al}_{2} \mathrm{O}_{3}$ and $\mathrm{AlN}$-precipitates were also formed in this alloy, but internal $\mathrm{Al}_{2} \mathrm{O}_{3}$ became continuous below the needle-like internal $\mathrm{Al}_{2} \mathrm{O}_{3}$ zone (Fig. 4b, e, and 7a). An external $\mathrm{Al}_{2} \mathrm{O}_{3}$ scale 
developed on the alloy with 5\% Cu addition (Fig. 4c and f, Fig. 7b), and a very thin Fe-oxide layer was observed on the surface of the $\mathrm{Al}_{2} \mathrm{O}_{3}$ scale. Penetration of spike-shaped $\mathrm{Al}_{2} \mathrm{O}_{3}$ occurred locally along with bright contrast phase, which is considered to be $\mathrm{ZrO}_{2}[14,15]$, suggesting that $\mathrm{Zr}$ content in this alloy is slightly over-doping. EPMA analysis shown in Fig. 7 reveals that $\mathrm{Cu}$ content is constant and $\mathrm{Cu}$ oxide formation was not confirmed.

Figure 5 shows cross-sections of $6 \mathrm{Al}$ and $15 \mathrm{Cr}$ alloys after oxidation for $100 \mathrm{~h}$. A thick duplex scale consisting of an outer Fe-Ni-oxide layer and an inner $\mathrm{Cr}_{2} \mathrm{O}_{3}$ layer formed on the alloy with $6 \mathrm{Al}$. Al was internally oxidized below the thick oxide scale. AlN formation below the internal $\mathrm{Al}_{2} \mathrm{O}_{3}$ precipitates was also observed. A continuous $\mathrm{Al}_{2} \mathrm{O}_{3}$ scale was formed on the $15 \mathrm{Cr}$ alloy, but the low $\mathrm{Cr}$ content resulted in the formation of an outer $\mathrm{Fe}(\mathrm{Ni})$ and $\mathrm{Cr}$-rich oxide layers above the $\mathrm{Al}_{2} \mathrm{O}_{3}$ scale. The initial rapid increase in oxidation mass gain of this alloy could be due to formation of this outer $\mathrm{Fe}(\mathrm{Ni})$ and $\mathrm{Cr}$-rich oxide layer; nevertheless, the inner $\mathrm{Al}_{2} \mathrm{O}_{3}$ layer was thin and formed over the entire surface of the alloy; therefore, the oxidation rate of this alloy decreased and became comparable to that of $\mathrm{Fe}-17 \mathrm{Ni}-17 \mathrm{Cr}-7.7 \mathrm{Al}-5 \mathrm{Cu}$ alloy. Figure 6 shows the cross-sections of Fe-24Ni-17Cr-7.7Al alloy after 100h of oxidation. The oxide scale formed on this alloy was almost same as the oxide scale formed on Fe-17Ni-17Cr-7.7Al. Higher Ni content did not improve the oxidation behaviour, indicating that $\mathrm{Cu}$ addition is beneficial for establishment of an $\mathrm{Al}_{2} \mathrm{O}_{3}$ scale.

\section{$<$ Ni-based alloys $>$}

Figure 8 shows cross-sections of $\mathrm{Ni}-17 \mathrm{Cr}-10 \mathrm{Al}$ alloy and $\mathrm{Ni}-17 \mathrm{Cr}-10 \mathrm{Al}$ with 5,10 , and $15 \mathrm{Cr}$ alloys after $100 \mathrm{~h}$ of oxidation. Ni-17Cr-10Al and $5 \mathrm{Cu}$ alloys formed a thick oxide scale. Based on the EPMA analysis shown in Fig. 9, the thick oxide scale consists of an $\mathrm{NiO}, \mathrm{Cr}_{2} \mathrm{O}_{3}, \mathrm{NiCrAl}_{2} \mathrm{O}_{4}$, and $\mathrm{Al}_{2} \mathrm{O}_{3}$ layers in this order. However, 10 and $15 \mathrm{Cu}$ alloys formed a very thin oxide scale. This oxide scale consisted of an outer thin $\mathrm{NiAl}_{2} \mathrm{O}_{4}$ and an inner $\mathrm{Al}_{2} \mathrm{O}_{3}$ layers. Similar to Fe-based alloys, penetration of $\mathrm{Al}_{2} \mathrm{O}_{3}$ into the alloy substrate was observed along with the $\mathrm{Zr}$ internal oxide precipitates.

Figure 10 shows the cross-sections of Ni-based alloys after $4 \mathrm{~h}$ of oxidation. A duplex oxide scale with an outer $\mathrm{NiO}$ and an inner $\mathrm{Cr}_{2} \mathrm{O}_{3}$ layers was formed on the $\mathrm{Ni}-17 \mathrm{Cr}-10 \mathrm{Al}$ and $-5 \mathrm{Cu}$ alloys, although most of the outer $\mathrm{NiO}$ scale formed on $\mathrm{Ni}-17 \mathrm{Cr}-10 \mathrm{Al}$ was spalled. An internal $\mathrm{Al}_{2} \mathrm{O}_{3}$ zone was observed in both alloys, but internal $\mathrm{Al}_{2} \mathrm{O}_{3}$ precipitates were connected to form a continuous $\mathrm{Al}_{2} \mathrm{O}_{3}$ layer on $\mathrm{Ni}-17 \mathrm{Cr}-10 \mathrm{Al}-5 \mathrm{Cu}$. The oxide structure formed on $10 \mathrm{Cu}$ alloy was similar to that formed on $5 \mathrm{Cu}$ alloy but the oxide scale was much thinner than that formed on $5 \mathrm{Cu}$. 
A continuous $\mathrm{Al}_{2} \mathrm{O}_{3}$ scale was developed on $10 \mathrm{Cu}$ alloy at this oxidation time. An external $\mathrm{Al}_{2} \mathrm{O}_{3}$ scale, which contains $\mathrm{NiAl}_{2} \mathrm{O}_{4}$ precipitates (bright contrast) in the outer part of oxide scale was developed on the alloy with $15 \mathrm{Cu}$.

Because internal $\mathrm{Al}_{2} \mathrm{O}_{3}$ precipitates became a continuous $\mathrm{Al}_{2} \mathrm{O}_{3}$ layer with increasing $\mathrm{Cu}$ contents, it is apparently that $\mathrm{Cu}$ addition promotes the transition from internal to external $\mathrm{Al}_{2} \mathrm{O}_{3}$ scale formation, i.e., decreases the critical $\mathrm{Al}$ content to form an external $\mathrm{Al}_{2} \mathrm{O}_{3}$ scale.

\subsection{Initial Oxidation Behaviour of Ni-based alloys}

Figure 11 shows the initial oxidation behaviour of $\mathrm{Ni}-\mathrm{Cr}-\mathrm{Al}$ and $\mathrm{Ni}-\mathrm{Cr}-\mathrm{Al}-15 \mathrm{Cu}$ alloys obtained by in situ high-temperature XRD by means of synchrotron source. During heating to $1000^{\circ} \mathrm{C}$, both alloys initially formed $\mathrm{NiO}$, however, signals from $\mathrm{CuO}$ were also observed on the $15 \mathrm{Cu}$ alloy just before $\mathrm{NiO}$ formation. The greater $\mathrm{NiO}$ peak shift to the lower two theta angle around $2 \theta=23.7^{\circ}$ during heating on the $15 \mathrm{Cu}$ alloy comparing to the $\mathrm{Ni}-\mathrm{Cr}$ - $\mathrm{Al}$ suggests dissolution of $\mathrm{Cu}$-oxide in the NiO. Then the position of $\mathrm{NiO}$ peak moved back to the higher two theta angle due to the formation of $\mathrm{NiAl}_{2} \mathrm{O}_{4}$. Once $\mathrm{NiAl}_{2} \mathrm{O}_{4}$ was formed, signals from $\mathrm{Cu}$-oxides disappeared. The signals from $\mathrm{NiAl}_{2} \mathrm{O}_{4}$ were not observed on $\mathrm{Ni}-\mathrm{Cr}$ - $\mathrm{Al}$ alloy, but $\mathrm{NiCr}_{2} \mathrm{O}_{4}$ was detected after $\mathrm{Cr}_{2} \mathrm{O}_{3}$ formation on this alloy without $\mathrm{Cu}$. The signal from $\mathrm{Al}_{2} \mathrm{O}_{3}$ was also detected on this alloy, but where observed later than that on the alloy with $\mathrm{Cu}$. Those differences, as well as the crosssection after $4 \mathrm{~h}$ in Fig. 10a, indicate that the signal of $\mathrm{Al}_{2} \mathrm{O}_{3}$ observed on the Ni-Cr-Al alloy originates from internal $\mathrm{Al}_{2} \mathrm{O}_{3}$ precipitates. Thus, it is apparent that $\mathrm{Ni}-\mathrm{Cr}-\mathrm{Al}-15 \mathrm{Cu}$ alloy formed an $\mathrm{Al}_{2} \mathrm{O}_{3}$ scale below the $\mathrm{NiO}$ scale during the heating stage. However, $\mathrm{Cu}$ addition did not change the very initial transient oxidation behavior. Although $\mathrm{Cu}$-oxide formation was observed on Ni$\mathrm{Cr}-\mathrm{Al}-\mathrm{Cu}$ alloy, both alloys initially formed $\mathrm{NiO}$. Therefore, the beneficial effect of $\mathrm{Cu}$ could be attributed to factors such as changes in oxygen solubility and diffusivities of oxygen and $\mathrm{Al}$ in the alloy substrate as discussed below.

\section{DISCUSSION}

$\mathrm{Cu}$ addition was found to be beneficial for external $\mathrm{Al}_{2} \mathrm{O}_{3}$ scale formation on both the Fe and Nibased FCC alloy groups. Comparing the oxidation behaviour of $\mathrm{Fe}-17 \mathrm{Ni}-17 \mathrm{Cr}-7.7 \mathrm{Al}-5 \mathrm{Cu}$ $(\mathrm{Ni}+\mathrm{Cu}=22 \mathrm{at} \%)$ with $\mathrm{Fe}-24 \mathrm{Ni}-17 \mathrm{Cr}-7.7 \mathrm{Al}$ also supports the finding that $\mathrm{Cu}$ addition is beneficial to the formation of $\mathrm{Al}_{2} \mathrm{O}_{3}$ scale because replacement of $\mathrm{Ni}$ with $\mathrm{Cu}$ in the alloys significantly improved the oxidation performance. In case of Ni-based alloys, higher $\mathrm{Cu}$ additions were necessary to form an external $\mathrm{Al}_{2} \mathrm{O}_{3}$ scale even though alloys contained higher $\mathrm{Al}$ contents, $10 \%$ 
higher than that of Fe-based alloys; however, the beneficial effect of $\mathrm{Cu}$ was also confirmed. In the following section, we initially discuss the effect of $\mathrm{Cu}$ on $\mathrm{Al}_{2} \mathrm{O}_{3}$ scale formation on Ni-based alloys.

The beneficial effect of $\mathrm{Cu}$ on the formation of an external $\mathrm{Al}_{2} \mathrm{O}_{3}$ scale in Ni-based alloys was confirmed by Niu et al. $[16,17]$. They reported an external $\mathrm{Al}_{2} \mathrm{O}_{3}$ scale formation on the $\mathrm{Ni}-45 \mathrm{Cu}-$ $10 \mathrm{Al}$ at $900^{\circ} \mathrm{C}$ in $\mathrm{O}_{2}$, but the oxide scale formed on $\mathrm{Ni}-30 \mathrm{Cu}-10 \mathrm{Al}$ alloy was a duplex consisting of an outer Ni-Al spinel and inner $\mathrm{Al}_{2} \mathrm{O}_{3}$ layers. Formation of an internal $\mathrm{Al}_{2} \mathrm{O}_{3}$ zone was also formed locally below the $\mathrm{Al}_{2} \mathrm{O}_{3}$ scale on $30 \mathrm{Cu}$ alloy. It is known that $10 \mathrm{at} \% \mathrm{Al}$ is not sufficient to form an external $\mathrm{Al}_{2} \mathrm{O}_{3}$ scale on Ni-Al alloy $[18,19]$. They inferred that this beneficial effect of $\mathrm{Cu}$ is attributed to increasing $\mathrm{Al}$ diffusion in the substrate with higher $\mathrm{Cu}$ contents, which decreases the critical $\mathrm{Al}$ content to form an external $\mathrm{Al}_{2} \mathrm{O}_{3}$ scale. They also evaluated the critical $\mathrm{Al}$ content to form an external $\mathrm{Al}_{2} \mathrm{O}_{3}$ scale, which is smaller for $\mathrm{Cu}-\mathrm{Al}$ alloys thanfor $\mathrm{Ni}-\mathrm{Al}$ alloys, however, assessment of the critical $\mathrm{Al}$ content on ternary $\mathrm{Ni}-\mathrm{Cu}-\mathrm{Al}$ system was not conducted.

The transition from internal to external $\mathrm{Al}_{2} \mathrm{O}_{3}$ scale formation is attributed to the higher permeability of $\mathrm{Al}, \mathrm{N}_{\mathrm{Al}} \mathrm{D}_{\mathrm{Al}}$, than that of oxygen, $\mathrm{N}_{\mathrm{O}} \mathrm{D}_{\mathrm{O}}$, in the alloy substrate [20]. $\mathrm{Cu}$ may have an effect on those permeabilities; however, to our knowledge no studies have reported on the permeability of $\mathrm{O}$ and $\mathrm{Al}$ in both the Fe-Ni-Cr-Al-Cu and Ni-Cr-Al-Cu alloys.

The effect of $\mathrm{Cu}$ on the concentration of oxygen, No, in Ni-Cu alloy can be evaluated by eq(1) which was proposed by Jacobs and Alcock [21].

$$
N_{N i}\left(\frac{\gamma_{N i(N i-C u)}^{\alpha}}{\gamma_{O(N i)}^{1 / n}}\right)+N_{C u}\left(\frac{\gamma_{C u(N i-C u)}^{\alpha}}{\gamma_{O(C u)}^{1 / n}}\right)=\left(\frac{1}{\gamma_{O(N i-C u)}^{1 / n}}\right)
$$

where $\gamma_{\mathrm{Ni}(\mathrm{Ni}-\mathrm{Cu})}$ and $\gamma_{\mathrm{Cu}(\mathrm{Ni}-\mathrm{Cu})}$ are the activity coefficients of $\mathrm{Ni}$ and $\mathrm{Cu}$ in the $\mathrm{Ni}-\mathrm{Cu}$ alloy, respectively. $\gamma_{O(i)}(\mathrm{i}=\mathrm{Ni}, \mathrm{Cu}$, or $\mathrm{Ni}-\mathrm{Cu})$ is the oxygen activity coefficient. $N_{N i}$ and $N_{C u}$ are the mole fraction of $\mathrm{Ni}$ and $\mathrm{Cu}$, respectively. $\alpha$ is the degree to which metal-metal bods are weakened and $\mathrm{n}$ is the number of bonds made by oxygen [x]. Then the oxygen mole fraction, $N_{O}$ can be calculated at given oxygen potential $\mathrm{P}_{\mathrm{O} 2}$ by following equation with the Seivert's law.

$$
K_{S}=\frac{N_{O}}{P_{O_{2}}^{1 / 2}}=\frac{1}{\gamma_{O}}
$$

Figure 12 shows the oxygen mole fraction as a function of $\mathrm{Cu}$ contents in $\mathrm{Ni}-\mathrm{Cu}$ alloy. The oxygen mole fraction was calculated using eq(1) with $\alpha=1 / 2$ and $n=4$ [21] at the oxygen partial pressure of $\mathrm{Ni} / \mathrm{NiO}$ equilibrium at $1000^{\circ} \mathrm{C}, \mathrm{P}_{\mathrm{O} 2}=4.68 \times 10^{-12} \mathrm{~atm}$, with $\gamma_{O(N i)}=0.0047$ and $\gamma_{O(\mathrm{Cu})}=6.9982$, which were calculated from [22-24]. The activity coefficients, $\gamma_{N i(N i-C u)}$ and $\gamma_{\mathrm{Cu}(\mathrm{Ni}-\mathrm{Cu})}$ were obtained from [25]. The oxygen mole fraction is shown to decrease with 
increasing $\mathrm{Cu}$ contents. The oxygen mole fraction in $15 \mathrm{Cu}$ alloy is about $60 \%$ of that in $\mathrm{Ni}$.

No data of diffusivity of oxygen and aluminum are also available for the Ni-Cu-Al system. Therefore, we conducted internal oxidation experiments of ternary Ni-Cu-Al alloys in Rhines pack method at the oxygen partial pressure of the $\mathrm{Ni} / \mathrm{NiO}$ equilibrium at $1000^{\circ} \mathrm{C}$. Figure 13 shows the internal oxidation kinetics of $\mathrm{Ni}-3 \mathrm{Al}$ and $\mathrm{Ni}-3 \mathrm{Al}-30 \mathrm{Cu}$ alloys. Internal oxidation kinetics of $30 \mathrm{Cu}$ alloy were higher than that of Ni-3Al. The cross-sections of alloys after $64 \mathrm{~h}$ of oxidation are shown in Fig. 14, revealing that rod-like internal $\mathrm{Al}_{2} \mathrm{O}_{3}$ precipitates were formed on both alloys, with a higher volume fraction of internal precipitates formed in $30 \mathrm{Cu}$ than that formed in Ni-3Al alloy (Fig. 15). Al depletion was observed in both alloys below the internal oxidation zone as shown in Figs. 14c and d, and the thickness of the $\mathrm{Al}$ depletion zone was greater for $30 \mathrm{Cu}$ alloy. This agrees with higher volume fraction of internal precipitates in $30 \mathrm{Cu}$ alloy, suggesting that the outward $\mathrm{Al}$ diffusion in $30 \mathrm{Cu}$ alloy was higher than that in $\mathrm{Ni}-3 \mathrm{Al}$ alloy.

Under the condition that the outward Al diffusion cannot be neglected, the internal oxidation kinetics are given by [20] with the effective diffusion coefficient of oxygen, $D_{O, e f f}$.

$$
X=\frac{\sqrt{\pi} t^{1 / 2} N_{O}^{(s)} D_{O, e f f}}{2 v N_{A l}^{(0)} D_{A l}^{1 / 2}}
$$

where $N_{O}^{(s)}$ and $N_{A l}^{(0)}$ are the oxygen mole fraction at the surface and the initial Al mole fraction in the alloy, $D_{O, e f f}$ and $D_{A l}$ are the effective oxygen and aluminium diffusion coefficients, respectively. $v$ is the ratio of oxygen to metal atoms in the oxide and is 1.5 for $\mathrm{Al}_{2} \mathrm{O}_{3}$. Because the rod-like internal precipitates which formed perpendicularly to the surface, the oxygen diffusion along the $\mathrm{Al}_{2} \mathrm{O}_{3} /$ substrate interface is enhanced. The effective diffusion coefficient of oxygen, $D_{O, e f f}$, can be calculated by [26] with the assumption of a cylindrical rod-like $\mathrm{Al}_{2} \mathrm{O}_{3}$ precipitate with a radius of $r$.

$$
\frac{D_{O, e f f}}{D_{O}}=1+\left[\frac{D_{O, i} \delta_{i}}{D_{o}} \frac{3}{r}-1\right] \frac{V_{o x}}{V_{\text {alloy }}} N_{A l 2 O 3}
$$

where $N_{A l 203}$ is mole fraction of $\mathrm{Al}_{2} \mathrm{O}_{3}$ in the substrate and $\delta_{i}$ is the width of the internal $\mathrm{Al}_{2} \mathrm{O}_{3} /$ substrate interface. $D_{O}$ and $D_{O, i}$ are the diffusion coefficients of oxygen in the alloy substrate and at the internal $\mathrm{Al}_{2} \mathrm{O}_{3} /$ substrate interface, and $V_{O X}$ and $V_{\text {alloy }}$ are molar volume of $\mathrm{Al}_{2} \mathrm{O}_{3}$ and alloy, respectively. With the assumption that all parameters except $D_{O, e f f}$ and $D_{O}$ in eq(4) are constant, the effective diffusion coefficient of oxygen in $30 \mathrm{Cu}$ alloy must be higher than that in Ni-3Al alloy because of its higher $N_{A l 2 O 3}$. In most of internal oxidation studies of Fe-Al and $\mathrm{Ni}-\mathrm{Al}$ alloys, the internal oxidation kinetics decrease with increases in $\mathrm{Al}$ content $[27,28]$, because $\mathrm{Al}_{2} \mathrm{O}_{3}$ precipitates become a barrier for the oxygen inward diffusion due to higher volume 
fraction of internal precipitates. However, in the present study, the internal oxidation kinetics of $30 \mathrm{Cu}$ alloy with higher $N_{A l 2 O 3}$ were higher than that of Ni-3Al. This opposite trend on internal oxidation kinetics was also observed in the study of oxidation of Ni-low Al alloys in $\mathrm{N}_{2}-20 \% \mathrm{O}_{2}$ at $800^{\circ} \mathrm{C}$ [29], and can be explained when $D_{O}$ is much smaller than $D_{O, i}$ in $\mathrm{Cu}$ containing alloys, i.e., contribution of the oxygen diffusion flux along the interface become much stronger in the alloy with $\mathrm{Cu}$.

Using eqs (3) and (4), the effect of $\mathrm{Cu}$ on the oxygen and $\mathrm{Al}$ diffusion coefficients can be evaluated, however, because each coefficient depends on $\mathrm{Cu}$ content, evaluation of the individual diffusion coefficients is not possible. A more detailed internal oxidation study as well as a diffusion study in the Ni-Cu-Al system are necessary for further discussion. However, it is apparent that $\mathrm{Cu}$ addition reduces the oxygen mole fraction in the alloy surface (Fig. 12) and enhance the $\mathrm{Al}$ outward diffusion. Those factors can promote an external $\mathrm{Al}_{2} \mathrm{O}_{3}$ scale formation on $\mathrm{Cu}$ containing alloys.

Doi et al. reported $\mathrm{Cu}$ segregation at the $\mathrm{Cr}_{2} \mathrm{O}_{3}$ /substrate interface on $\mathrm{Ni}-\mathrm{Cr}$ alloy after very short-term oxidation, $300 \mathrm{~s}$, at $650^{\circ} \mathrm{C}$ in $60 \% \mathrm{CO}-26 \% \mathrm{H}_{2}-11.5 \% \mathrm{CO}_{2}-2.5 \% \mathrm{H}_{2} \mathrm{O}$ by the hard $\mathrm{X}$-ray photoelectron spectroscopy by means of synchrotron source [30]. The thickness of Cusegregation layer formed below the $\mathrm{Cr}_{2} \mathrm{O}_{3}$ scale was about $0.25 \mathrm{~nm}$ and $\mathrm{Cu}$ content was about $50 \%$. Although the alloy and oxidation condition in the present study is different, $\mathrm{Cu}$ segregation at the scale/alloy interface in the initial oxidation stage in the present study is expected, because $\mathrm{Cu}$ cannot be oxidized once a $\mathrm{NiO}$ scale is formed as shown in Fig. 11. Once $\mathrm{Cu}$ is segregated, it further decreases the surface oxygen mole fraction and could increase Al diffusion. Those factors promote an $\mathrm{Al}_{2} \mathrm{O}_{3}$ scale formation.

$\mathrm{Cu}$ addition in Fe-based alloys was more effective than Ni-based alloys. The solubility of oxygen in FCC Fe-Ni system is reported to increase with increase in Fe content [31]. The diffusion coefficient of oxygen at $1000^{\circ} \mathrm{C}$ in $\mathrm{FCC} \mathrm{Fe}, 2.0 \times 10^{-7} \mathrm{~cm}^{2} / \mathrm{s}$ [27] is much higher than that in $\mathrm{Ni}$, $9.1 \times 10^{-9} \mathrm{~cm}^{2} / \mathrm{s}$ [22]. Although the available diffusion coefficients in Fe-Ni-Al system are only at $1000^{\circ} \mathrm{C}, \mathrm{Fe} / \mathrm{Ni}$ ratio does not affect the main-term interdiffusion coefficient, $\widetilde{D}_{A l A l}^{F e}[32,33]$. This suggest opposite oxidation behavior that the Fe-Ni-Al system requires higher critical Al content to form an external $\mathrm{Al}_{2} \mathrm{O}_{3}$ scale. However, it was reported that the cross-term interdiffusion coefficient of Al, $\widetilde{D}_{A l N i}^{F e}$ is negative and has a same order to the main-term diffusion coefficient in $[32,33]$. Figure 16 shows the GD-OES depth profile of Fe-17Ni-17Cr-7.7Al-7Cu alloy after 30 s of oxidation in air at $1000^{\circ} \mathrm{C}$. Ni-enrichment was observed just below the oxide scale, this would be caused by Fe-depletion due to formation of an Fe-oxide in the transient oxidation period. 
As it proposed from the oxidation of Ni-Pt-Al alloys [34, 35], the outward Al diffusion at the subsurface region would be enhanced due to the negative cross-term coefficient and Nienrichment, which could further decrease the critical $\mathrm{Al}$ content to form the external $\mathrm{Al}_{2} \mathrm{O}_{3}$ scale on Fe-based alloys.

\section{CONCLUSIONS}

The oxidation of austenitic Fe-Ni-Cr-Al with and without $\mathrm{Cu}$ addition was carried out at $1000^{\circ} \mathrm{C}$ in air, and effect of $\mathrm{Cu}$ on the development of $\mathrm{Al}_{2} \mathrm{O}_{3}$ scale was investigated. The results obtained are summarized as follows.

1) Oxidation kinetics of $\mathrm{Fe}-\mathrm{Ni}-\mathrm{Cr}-\mathrm{Al}$ and $\mathrm{Ni}-\mathrm{Cr}-\mathrm{Al}$ alloys decreased with the increase in alloy $\mathrm{Cu}$ content. An external $\mathrm{Al}_{2} \mathrm{O}_{3}$ scale developed with the addition of $4 \mathrm{at} \% \mathrm{Cu}$ and $10 \mathrm{at} \% \mathrm{Cu}$ on the Fe-17Ni-17Cr-7.7Al and Ni-17Cr-10Al alloys, respectively.

2) The beneficial effect of $\mathrm{Cu}$ is attributed to decrease in the oxygen mole fraction in the alloy surface and enhanced Al outward diffusion.

3) The cross-term effect of $\mathrm{Ni}$ on $\mathrm{Al}$ outward diffusion in Fe-Ni-Cr-Al-Cu alloy could further decrease the $\mathrm{Al}$ and $\mathrm{Cu}$ contents to formation of the external $\mathrm{Al}_{2} \mathrm{O}_{3}$ scale.

\section{Acknowledgements}

This study was supported in a part by JSPS KAKENHI Grant Number JP15H04153. The synchrotron radiation experiments were performed at BL46 of SPring- 8 with the approval of the Japan Synchrotron Radiation Research Institute (JASRI) (Proposal No. 2015B1635 and 2016A1806).

\section{REFERENCE}

[1] P. Tomaszewicz and G.R. Wallwork, Corrosion-NACE, 40 (1984) 152-157.

[2] M. Sakiyama, P. Tomaszewicz, and G.R. Wallwork, Oxid. Met., 13 (1979), 311-330.

[3] L. Eleno, K. Frisk, and A. Schneider, Intermetallics, 14 (2006) 1276-1290.

[4] M.P. Brady, Y. Yamamoto, M.L. Santella, P.J. Maziasz, B.A. Pint, C.T. Liu, Z.P. Lu, and H. Bei, JOM, 60 (2008) 12-18.

[5] Y. Yamamoto, M.L. Santella, M.P. Brady, H. Bei and P.J. Maziasz, Metal. Mater. Trans. A, 40A (2009) 1868-1880.

[6] M.P. Brady, Y. Yamamoto, M.L. Santella, and B.A. Pint, Scripta Mater., 57 (2007) 1117-1120.

[7] Z. Sun, C.H. Liebscher, S. Huang, Z. Teng, G. Song, G. Wang, M. Asta, M. Rawlings, M.E. 
Fine, and P.K. Liaw, Scripta Mater. 68 (2013) 384-388.

[8] D.V.V. Satyanarayana, G. Malakondaiah, and D.S. Sarma, Mater. Sci. Eng., A323 (2002) 119128.

[9] C. Chi, H. Yu, J. Dong, W. Liu, S. Cheng, Z. Liu, and X. Xie, Prog. Natural Sci., 22 (2012) 175-185.

[10] K. laha, J. Kyono, and N. Shinya, Scripta Mater., 56 (2007) 915-918.

[11] K. Wambach, J. Peters, and H.J. Grabke, Mater. Sci. Eng., 88 (1987) 205-212.

[12] E.C. Dickey, B.A. Pint, K.B. Alexander, and I.G. Wright, J. Mater. Res., 14 (1999) 45314540 .

[13] S. Yoneda, S. Hayashi, I. Saeki and S. Ukai, Oxid. Met., 86 (2016) 357-370.

[14] C.H. Xu, W. Gao, and H. Gong, Intermetallics 8 (2000) 769-779.

[15] J. Klöwer, Mater. Corr., 51 (2000) 373-385.

[16] Y. Niu, J.H. Xiang, and G. Gesmundo, Oxid. Met., 60 (2003) 293-313.

[17] J.H. Xiang, G. Gesmundo, and Y. Niu, Corr. Sci., 46 (2004) 2025-2039.

[18] X.J. Zhang, S.Y. Wang, F. Gesmundo, and Y. Niu, Oxid. Met., 65 (2006) 151-165.

[19] F.S. Pettit, Trans. Met. Soc. AIME, 239 (1967) 1296-1305.

[20] C. Wagner, Z. Ekektrochem., 63 (1959) 772-782.

[21] K.T. Jacob and C.B. Alcock, Acta Metall., 20 (1972) 221-232.

[22] J-W. Park and C.J. Altstetter, Metal. Metall. Trans. A, 18A (1987) 43-50.

[23] B. Hallstedt, D. Risold, and L.J. Gauckler, J. Phase Equilibria, 15 (1994) 483-499.

[24] M.L. Narula, V.B. Tare, and W.L. Worrell, Metall. Trans. B, 14B (1983) 673-677.

[25] T. Oishi, S. Tagawa, and S. Tanegashima, Mater. Trans., 44 (2003) 1120-1123.

[26] D.P. Whittle, Y. Shida, G.C. Wood, F.H. Stott, and B.D. Bastow, Phi. Mag. A, 46 (1982) 931949.

[27] J. Takada, S. Yamamoto, S. Kikuchi, and M Adachi, Metall. Trans. A, 17A (1986) 221-229.

[28] A. Martinez-Villafane, F.H. Stott, JH.G. Chacon-Nava, and G.C. Wood, Oxid. Met., 75 (2002) 267-279.

[29] S. Hayashi, S. Narita, and T. Narita, Oxid. Met., 66 (2006) 191-207.

[30] T. Doi, K. Kitamura, Y. Nishiyama, N. Otsuka, T. Kudo, M. Sato, E. Ikenega, S. Ueda, and K. Kobayashi, Surf. Interface Anal., 40 (2008) 1374-1381.

[31] D. Jullian, J. Zhan, D. B. Hibbert, and D.J. Young, J. Alloy Comp., 732 (2018) 646-654.

[32] G.H. Cheng and M.A. Dayananda, Metall. Trans. A, 10A (1979) 1415-1419.

[33] Y.H. Sohn and M.A. Dayananda, Metall. Mater. Trans. A, 33A (2002) 3375-3392. 
[34] S. Hayashi, T. Narita, and B. Gleeson, Materials Science Forum, $522-523$ (2006) 229-238.

[35] S. Hayashi, W. Wang, D.J. Sordelet, and B. Gleeson, Metal. Mater. Trans. A, 36A (2005) $1769-1775$.

Caption list

Fig.1 Oxidation kinetics of Fe-based alloys at $1000^{\circ} \mathrm{C}$ in air

Fig. 2 Oxidation mass gain of $\mathrm{Fe}-17 \mathrm{Ni}-17 \mathrm{Cr}-7.7 \mathrm{Al}-\mathrm{Cu}$ alloys as a function of $\mathrm{Cu}$ contents

Fig. 3 Oxidation kinetics of Ni-based alloys at $1000^{\circ} \mathrm{C}$ in air

Fig. 4 Cross-sections of oxide scale formed on (a) (d) Fe-17Ni-17Cr-7.7Al, with (b) (e) $3.5 \mathrm{Cu}$ and (c) (f) $5 \mathrm{Cu}$ alloys after $100 \mathrm{~h}$ of oxidation in air at $1000^{\circ} \mathrm{C}$, (d) (e)(f) are enlarged images of boxed areas in $(\mathrm{a})(\mathrm{b})(\mathrm{c})$

Fig. 5 Cross-sections of oxide scale formed on (a) Fe-17Ni-17Cr-6Al-5Cu and (b) Fe-17Ni-15Cr7.7 Al-5Cu after $100 \mathrm{~h}$ of oxidation in air at $1000^{\circ}$

$\mathrm{C}$, (c) is enlarged image of (b)

Fig. 6 Cross-sections of oxide scale formed on Fe-24Ni-17Cr-7.7Al. (b) is enlarged image of (a).

Fig. 7 EPMA concentration profiles of each element of (a) Fe-17Ni-17Cr-7.7Al-3.5Cu and (b) Fe$17 \mathrm{Ni}-17 \mathrm{Cr}-7.7 \mathrm{Al}-5 \mathrm{Cu}$ after $100 \mathrm{~h}$ of oxidation in air at $1000^{\circ} \mathrm{C}$

Fig. 8 Cross-sections of oxide scale formed on (a) Ni-17Cr-10Al, with (b) $5 \mathrm{Cu},(\mathrm{c}) 10 \mathrm{Cu}$, and (d) $15 \mathrm{Cu}$ alloys after $100 \mathrm{~h}$ of oxidation in air at $1000^{\circ} \mathrm{C}$

Fig. 9 EPMA concentration profiles of each element of $17 \mathrm{Ni}-17 \mathrm{Cr}-10 \mathrm{Al}$ after $100 \mathrm{~h}$ of oxidation in air at $1000^{\circ} \mathrm{C}$

Fig. 10 Cross-sections of oxide scale formed on (a) Ni-17Cr-10Al, with (b) $5 \mathrm{Cu}$, (c) $10 \mathrm{Cu}$, and (d) $15 \mathrm{Cu}$ alloys after $4 \mathrm{~h}$ of oxidation in air at $1000^{\circ} \mathrm{C}$

Fig. 11 In-situ HT-XRD patterns of (a) Ni-17Cr-10Al and (b) Ni-17Cr-10Al-15Cu alloys during heating followed by isothermal oxidation in air at $1000^{\circ} \mathrm{C}$

Fig. 12 Effect of $\mathrm{Cu}$ on the oxygen solubility in $\mathrm{Ni}-\mathrm{Cu}$ system at $1000^{\circ} \mathrm{C}$

Fig. 13 Internal oxidation kinetics of $\mathrm{Ni}-3 \mathrm{Al}$ and $\mathrm{Ni}-3 \mathrm{Al}-30 \mathrm{Cu}$ at $1000^{\circ} \mathrm{C}$ in $\mathrm{Ni} / \mathrm{NiO}$ mixture Fig. 14 Cross-sections of (a) Ni-3Al and (b) Ni-3Al-30Cu after internal oxidation for $64 \mathrm{~h}$ at $1000^{\circ}$ $\mathrm{C}$

Fig. 15 Volume fraction of internal $\mathrm{Al}_{2} \mathrm{O}_{3}$ precipitates formed in $\mathrm{Ni}-3 \mathrm{Al}$ and $\mathrm{Ni}-3 \mathrm{Al}-30 \mathrm{Cu}$ alloys Fig. 16 GD-OES concentration profiles of each element of (a) Fe-17Ni-17Cr-7.7Al and (b) Fe- 
$17 \mathrm{Ni}-15 \mathrm{Cr}-7.7 \mathrm{Al}-7 \mathrm{Cu}$ after $30 \mathrm{~s}$ of oxidation in air at $1000^{\circ}$

Table 1 Composition of alloys (nominal in at\%) 
Table 1 Composition of alloys

(nominal in at $\%$ )

\begin{tabular}{|c|c|c|c|c|c|c|}
\hline & $\mathrm{Fe}$ & $\mathrm{Cr}$ & $\mathrm{Ni}$ & $\mathrm{Al}$ & $\mathrm{Cu}$ & $\mathrm{Zr}$ \\
\hline \multirow{9}{*}{ Fe-based } & \multirow{9}{*}{ Bal. } & \multirow{8}{*}{17} & \multirow{7}{*}{17} & \multirow{6}{*}{7.7} & - & \multirow{13}{*}{0.03} \\
\hline & & & & & 3.5 & \\
\hline & & & & & 3.8 & \\
\hline & & & & & 4.3 & \\
\hline & & & & & 5 & \\
\hline & & & & & 7 & \\
\hline & & & & 6 & 5 & \\
\hline & & & 24 & 7.7 & - & \\
\hline & & 15 & 17 & 7.7 & 5 & \\
\hline \multirow{4}{*}{ Ni- based } & \multirow{4}{*}{-} & \multirow{4}{*}{17} & \multirow{4}{*}{ Bal. } & \multirow{4}{*}{10} & - & \\
\hline & & & & & 5 & \\
\hline & & & & & 10 & \\
\hline & & & & & 15 & \\
\hline
\end{tabular}




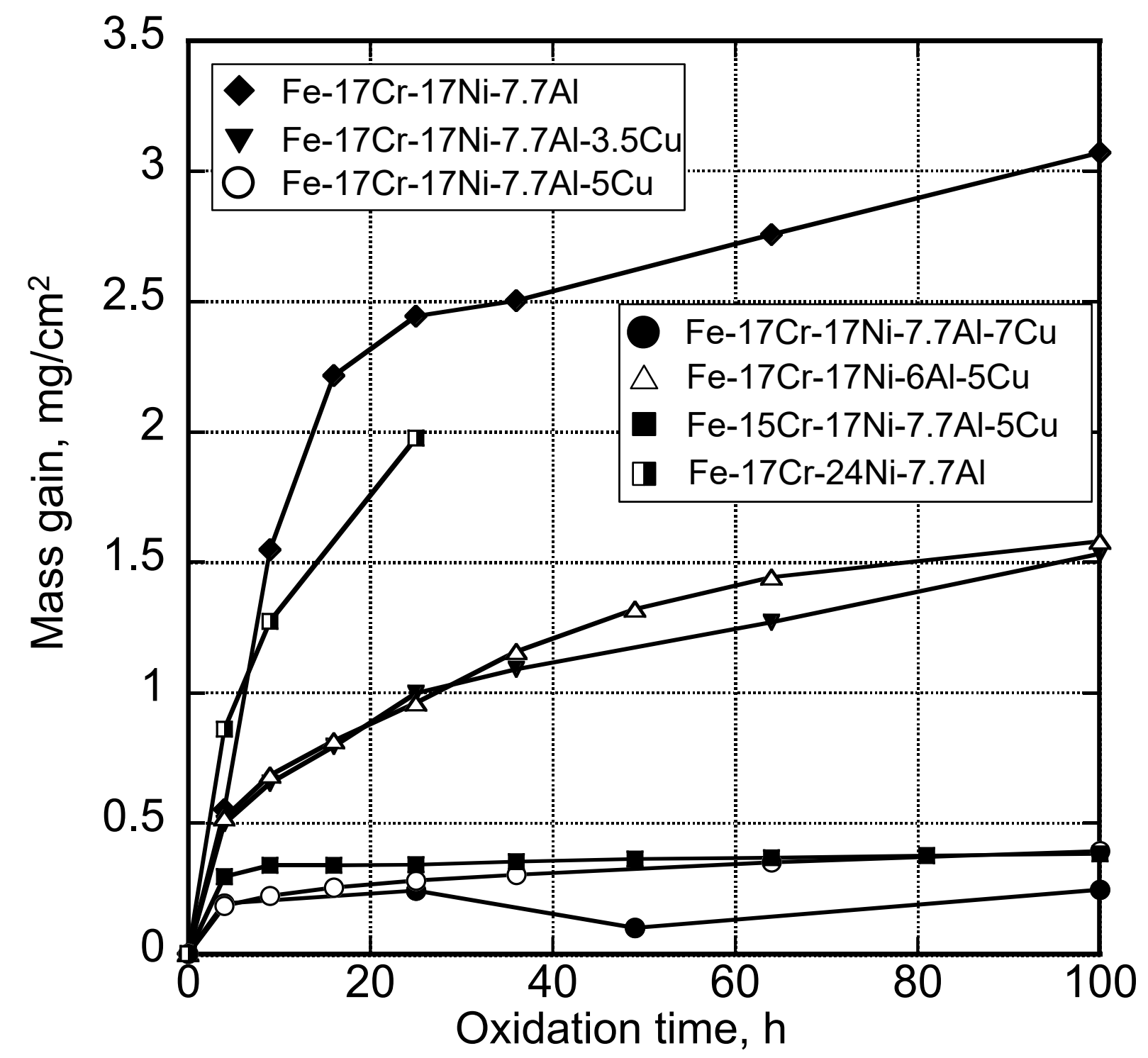

Fig. 1 Oxidation kinetics of Fe-based alloys at $1000^{\circ} \mathrm{C}$ in air 


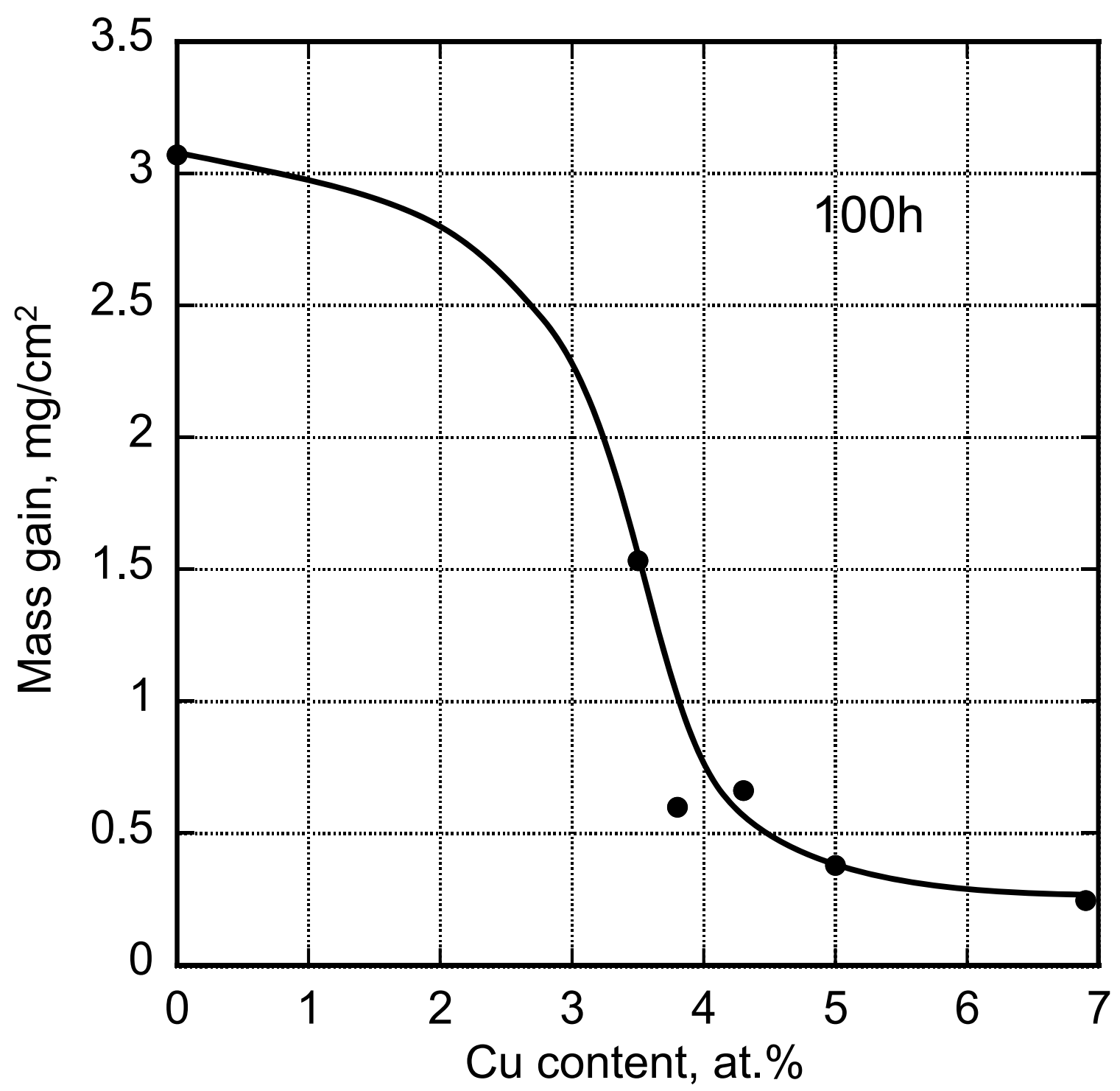

Fig. 2 Oxidation mass gain of $\mathrm{Fe}-17 \mathrm{Ni}-17 \mathrm{Cr}-7.7 \mathrm{Al}-\mathrm{Cu}$ alloys as a function of $\mathrm{Cu}$ contents 


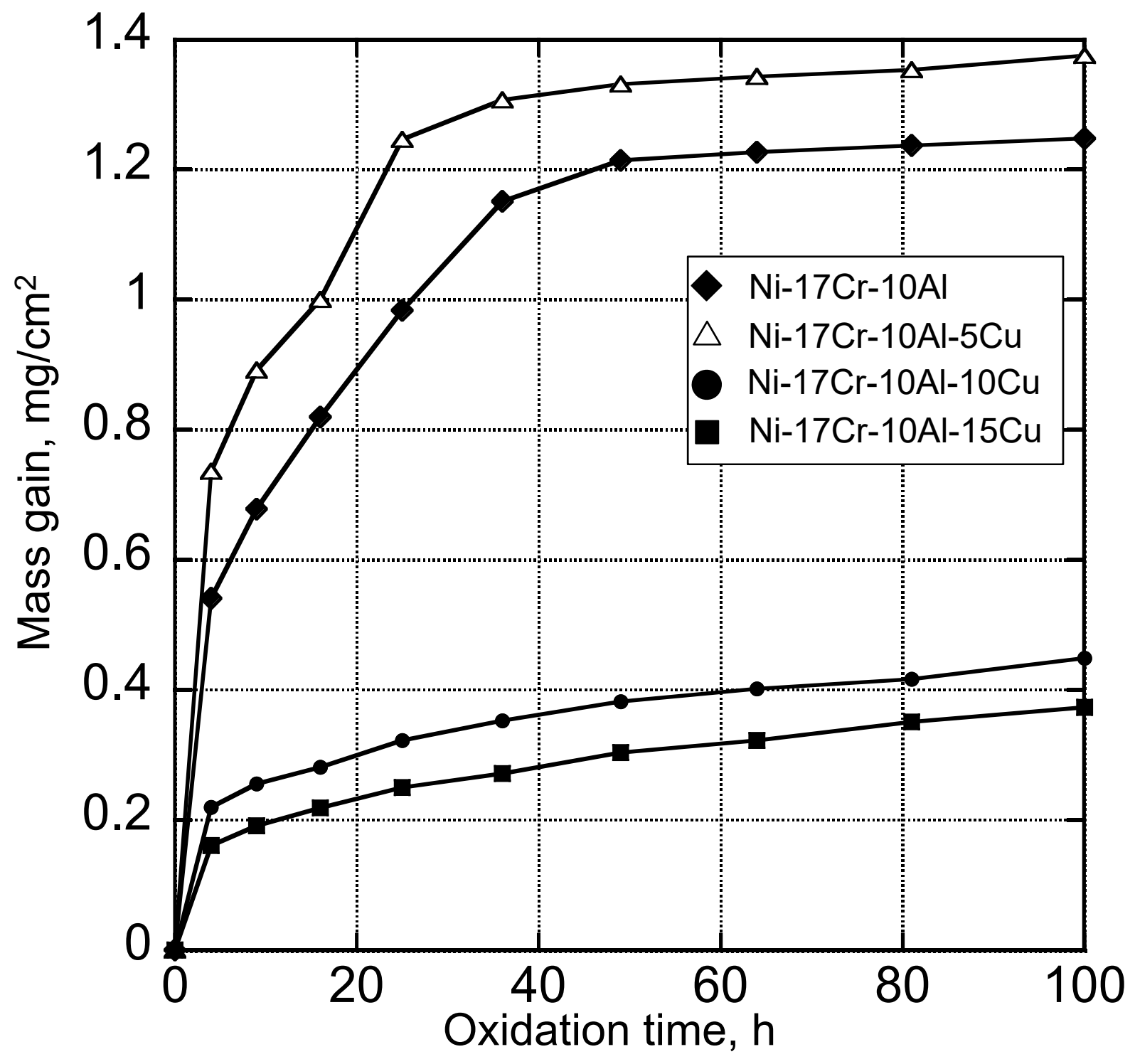

Fig. 3 Oxidation kinetics of Ni-based alloys at $1000^{\circ} \mathrm{C}$ in air 
(a)

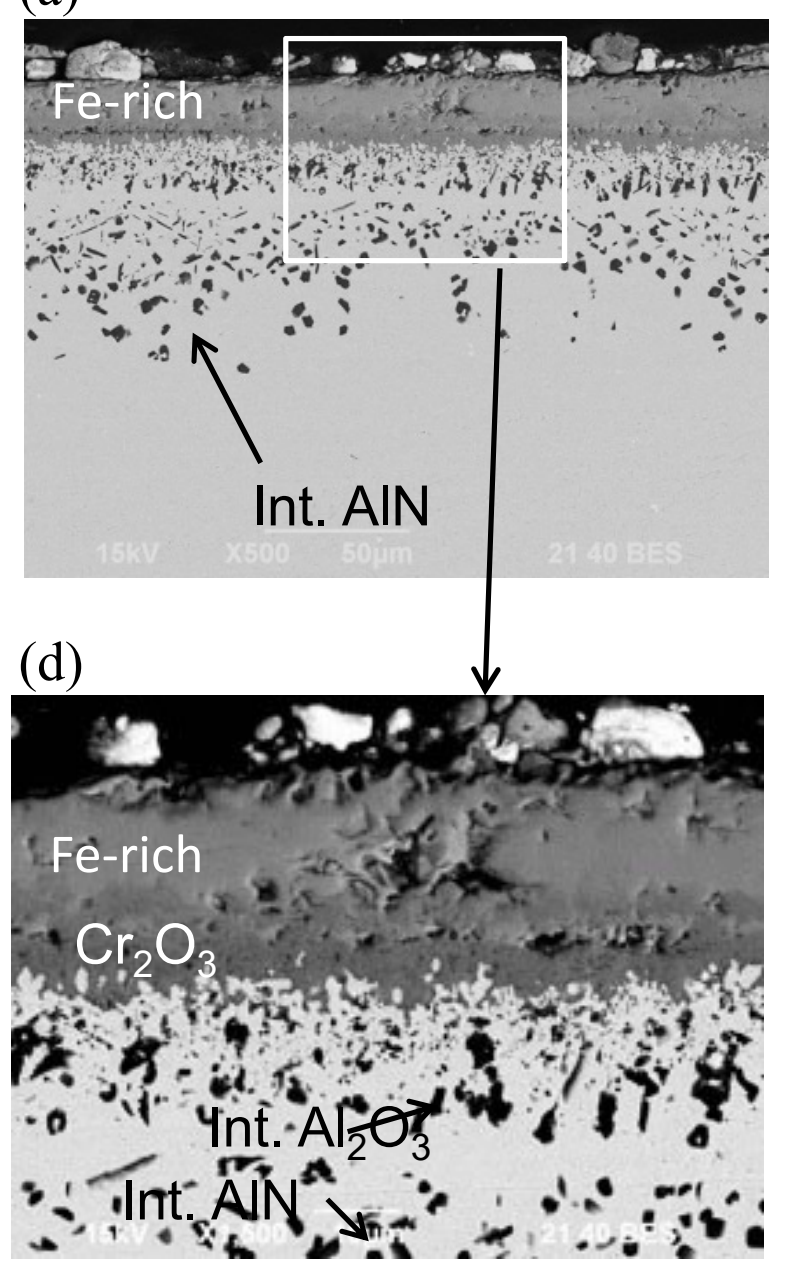

(b)

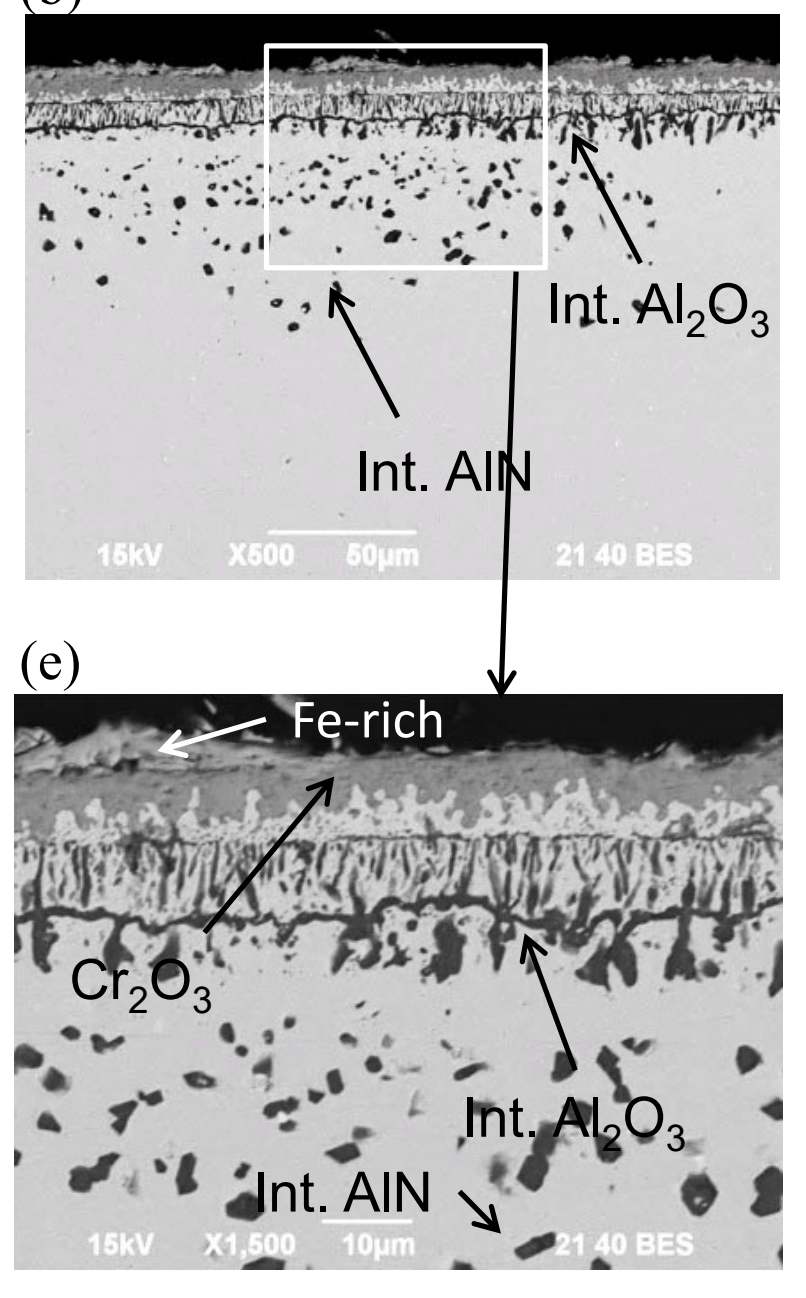

(c)

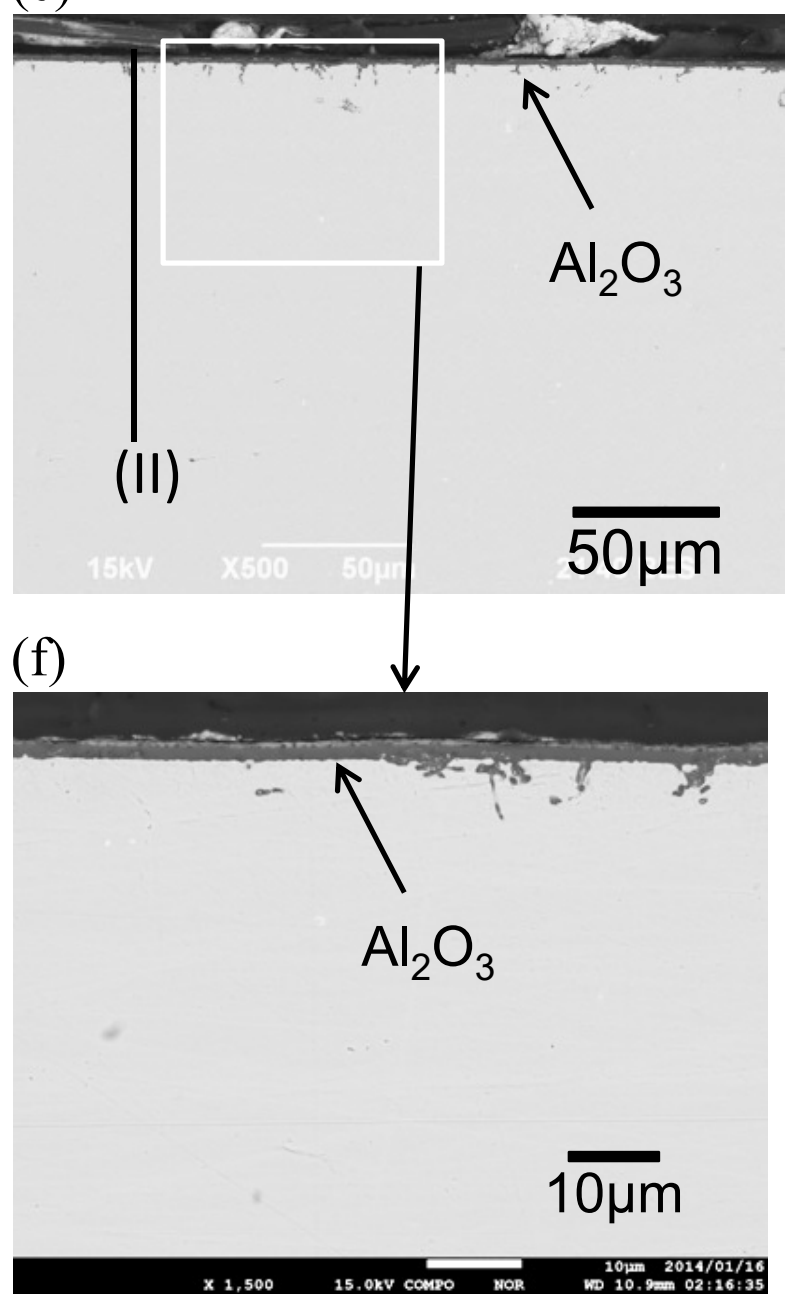

Fig. 4 Cross-sections of oxide scale formed on (a)(d) Fe-17Ni-17Cr-7.7Al, with (b)(e) 3.5Cu and (c)(f) 5Cu alloys after 100h of oxidation in air at $1000^{\circ} \mathrm{C},(\mathrm{d})(\mathrm{e})(\mathrm{f})$ are enlarged images of boxed areas in $(\mathrm{a})(\mathrm{b})(\mathrm{c})$ 
(a)

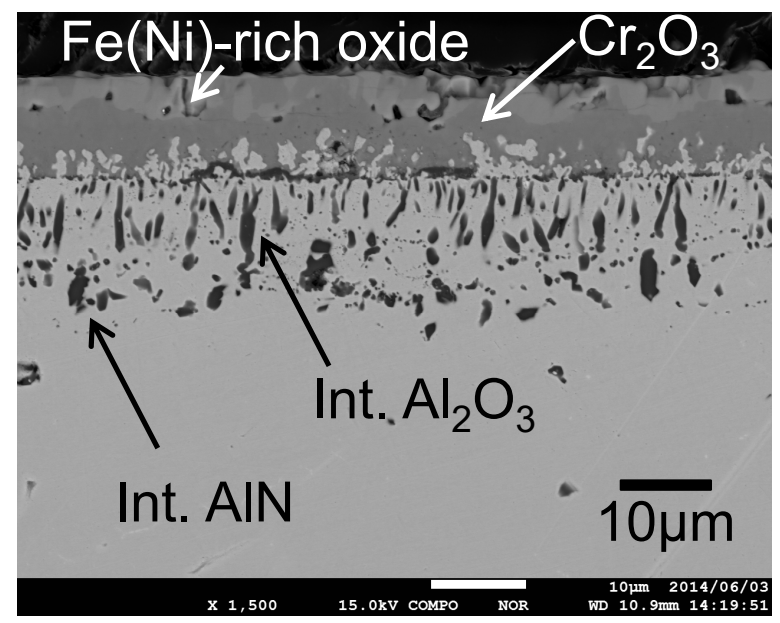

(b)
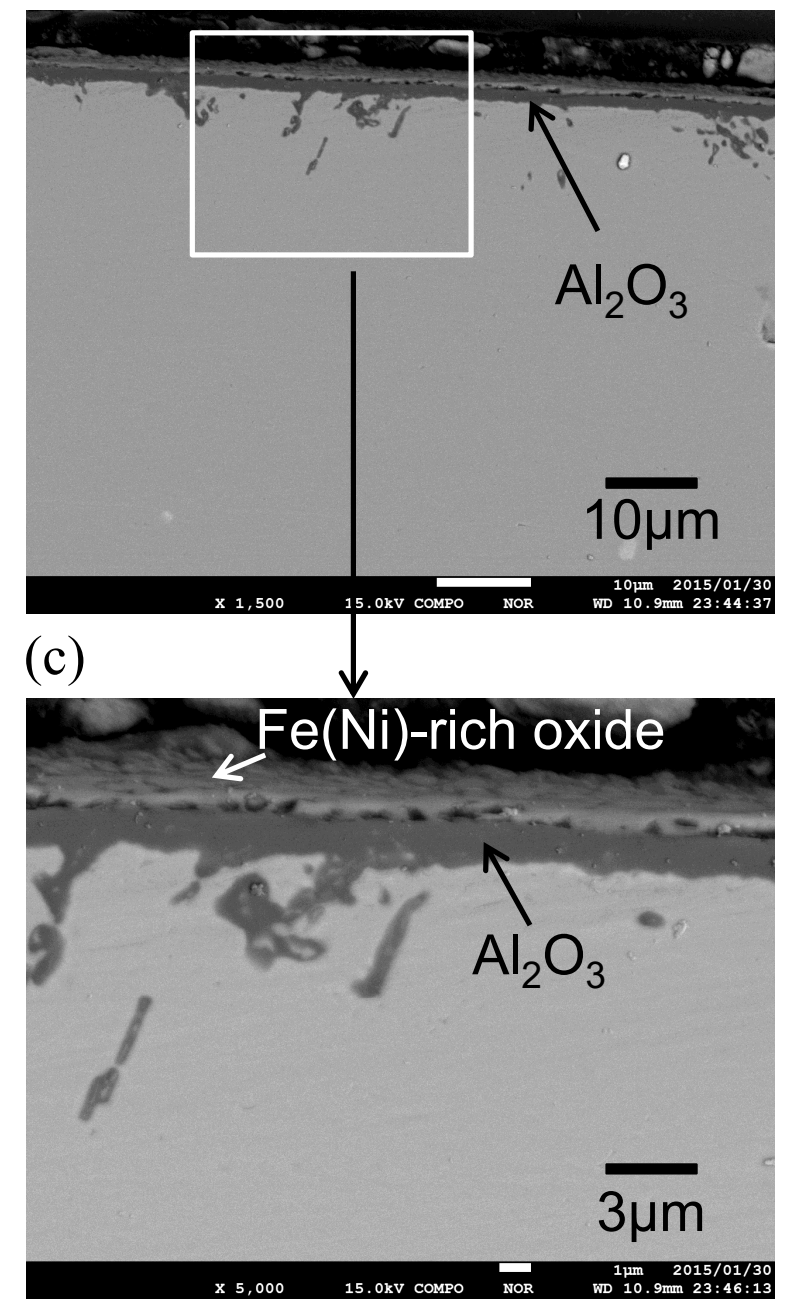
(a)

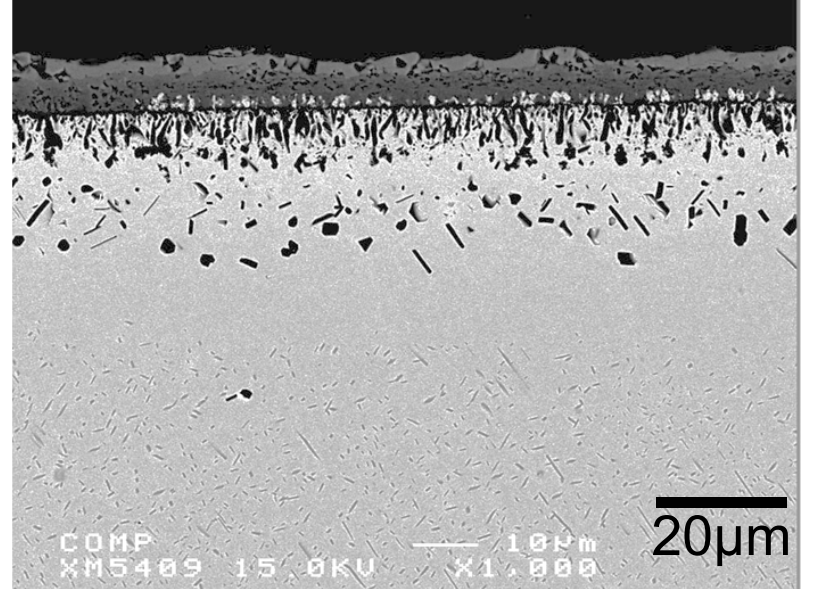

(b)

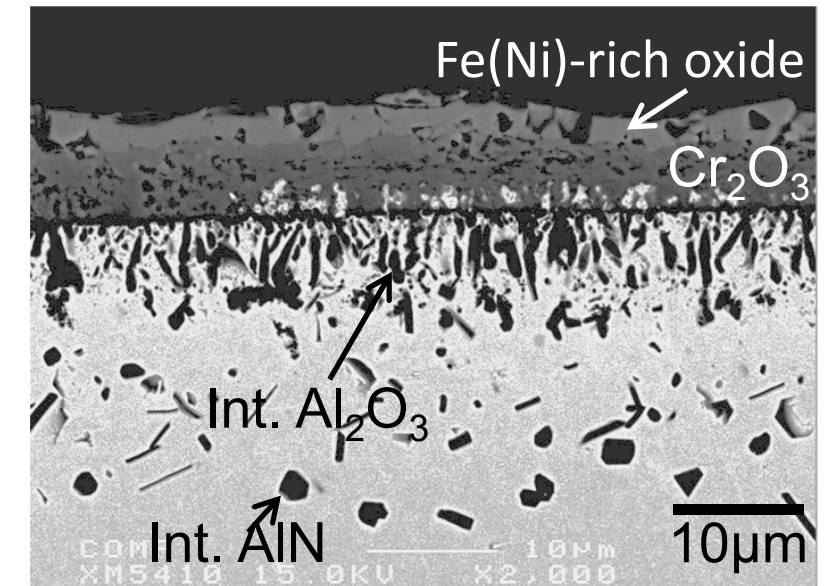


(a)

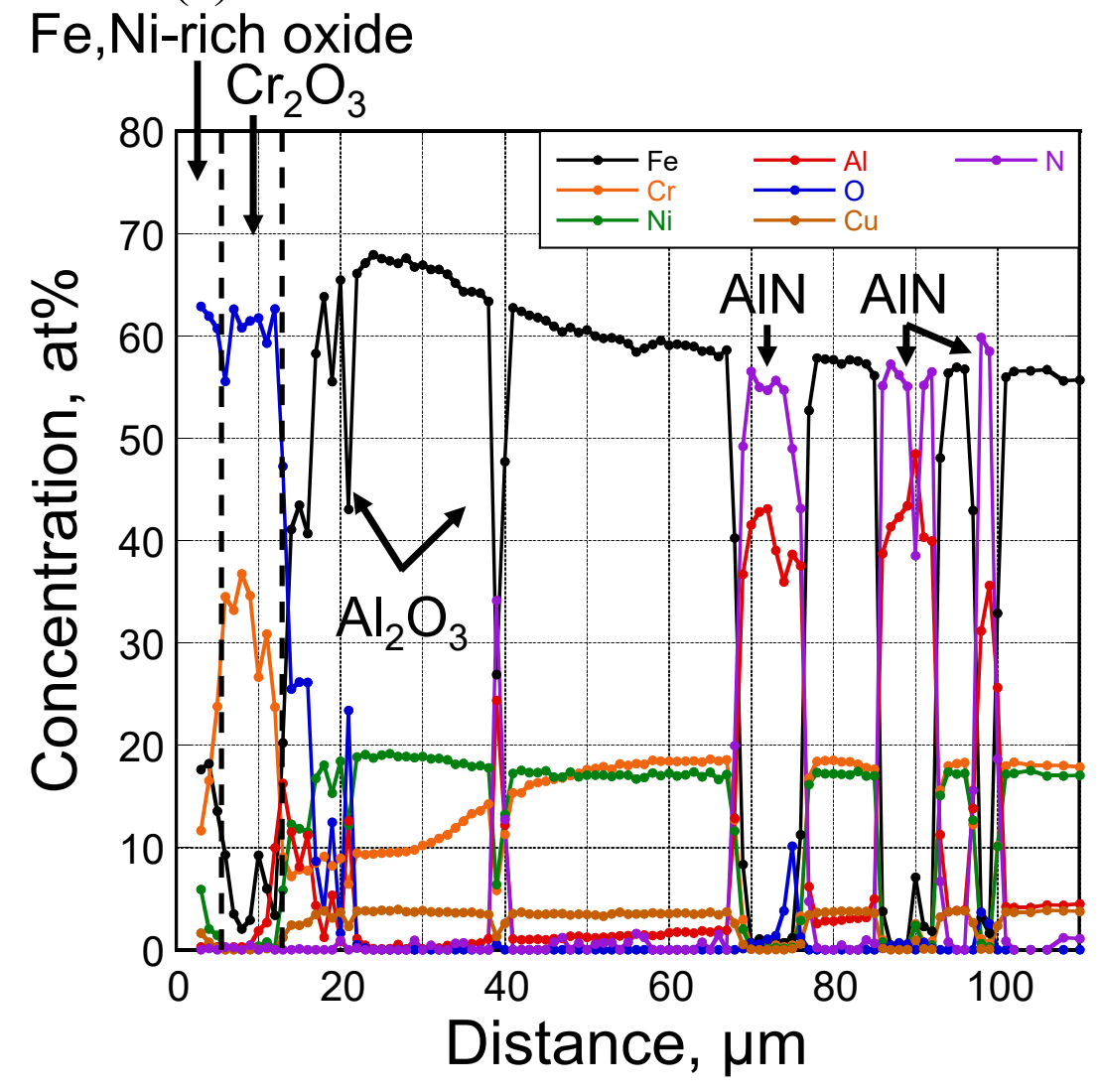

(b)

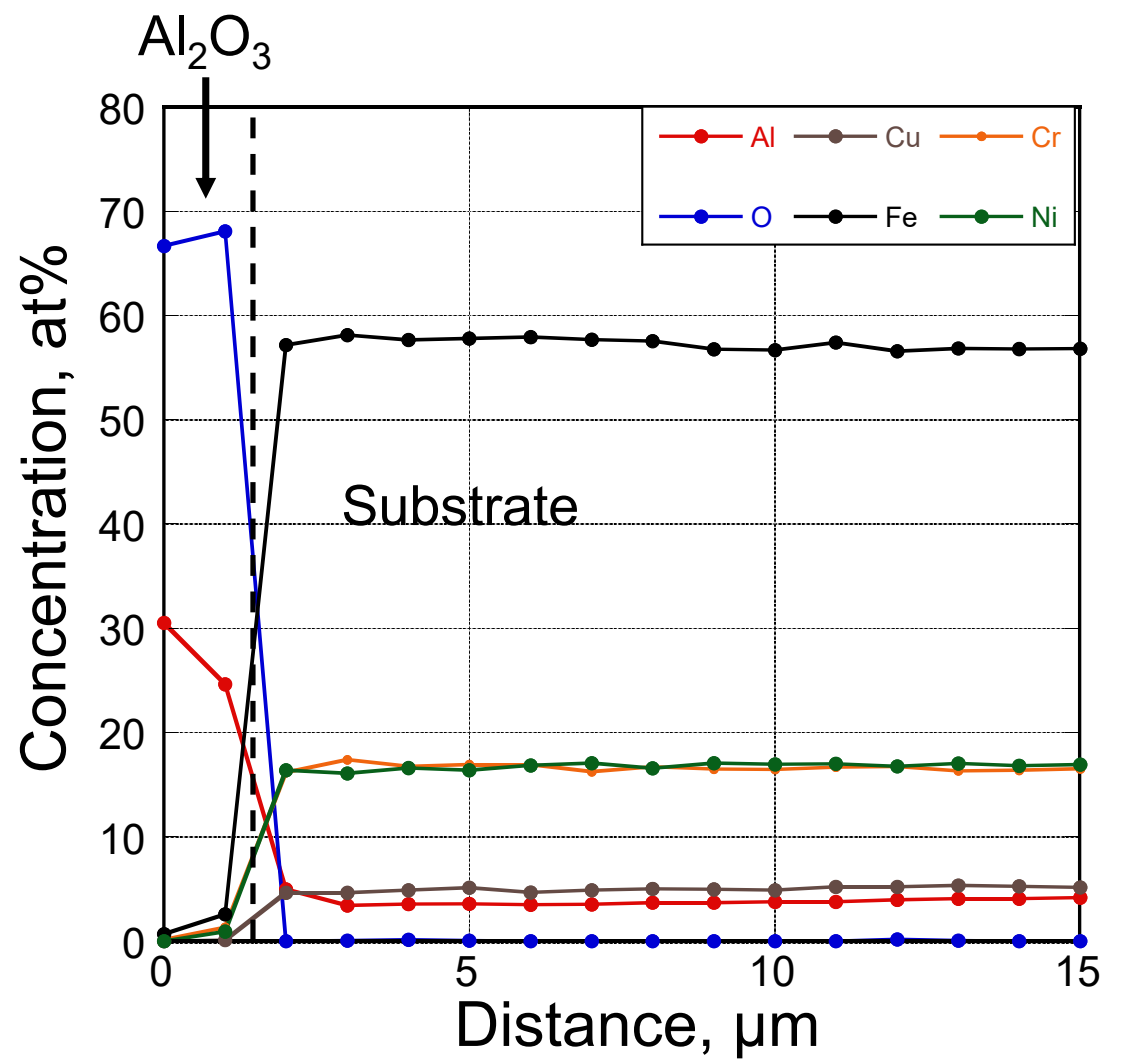


(a)

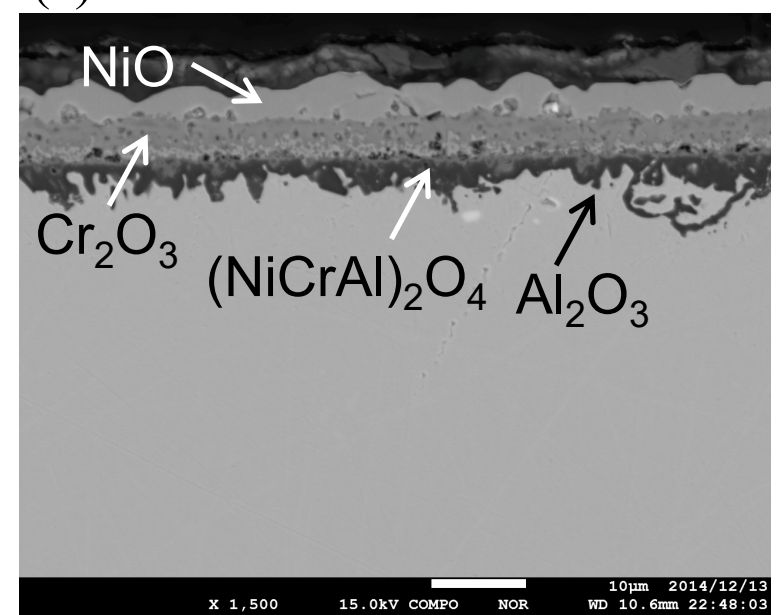

(d)

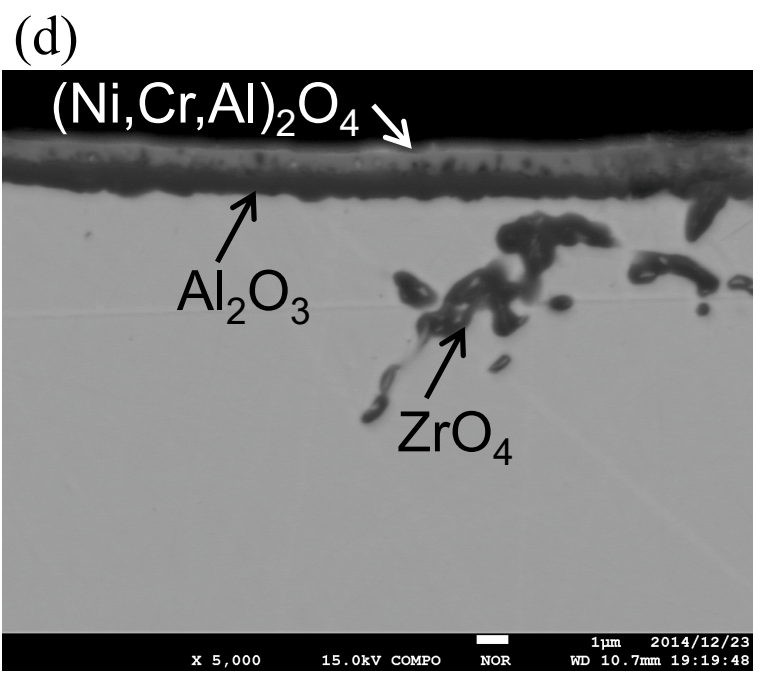

(b)

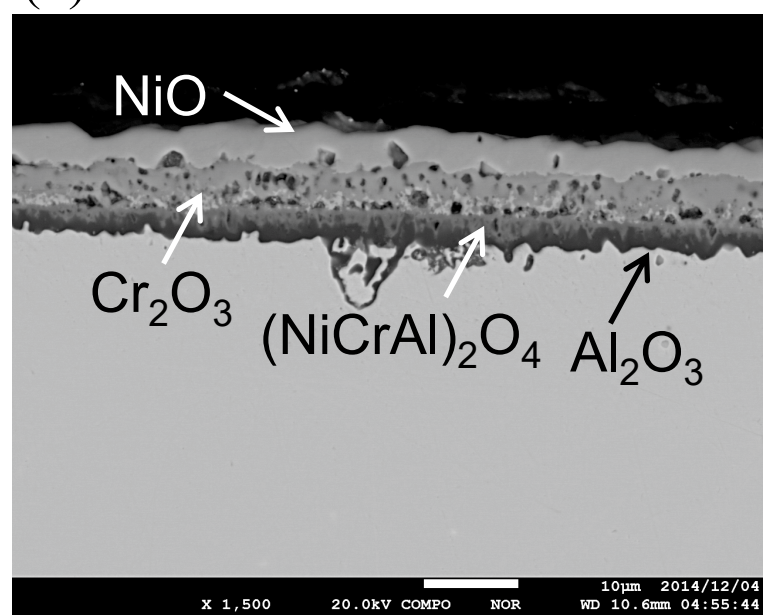

(c)

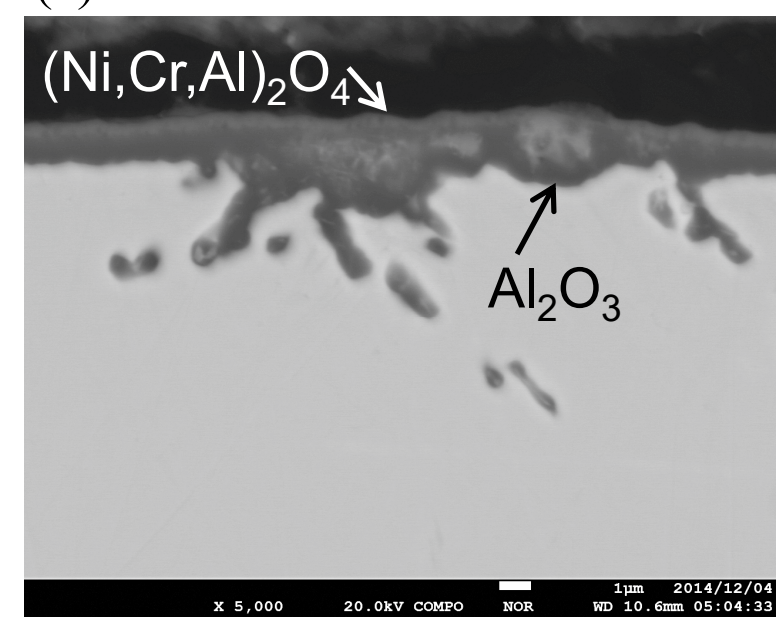

$\times 5,000$

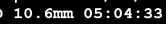

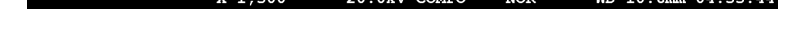

Fig. 8 Cross-sections of oxide scale formed on (a) Ni-17Cr-10Al, with (b) $5 \mathrm{Cu}$, (c) $10 \mathrm{Cu}$, and (d) $15 \mathrm{Cu}$ alloys after $100 \mathrm{~h}$ of oxidation in air at $1000^{\circ} \mathrm{C}$ 


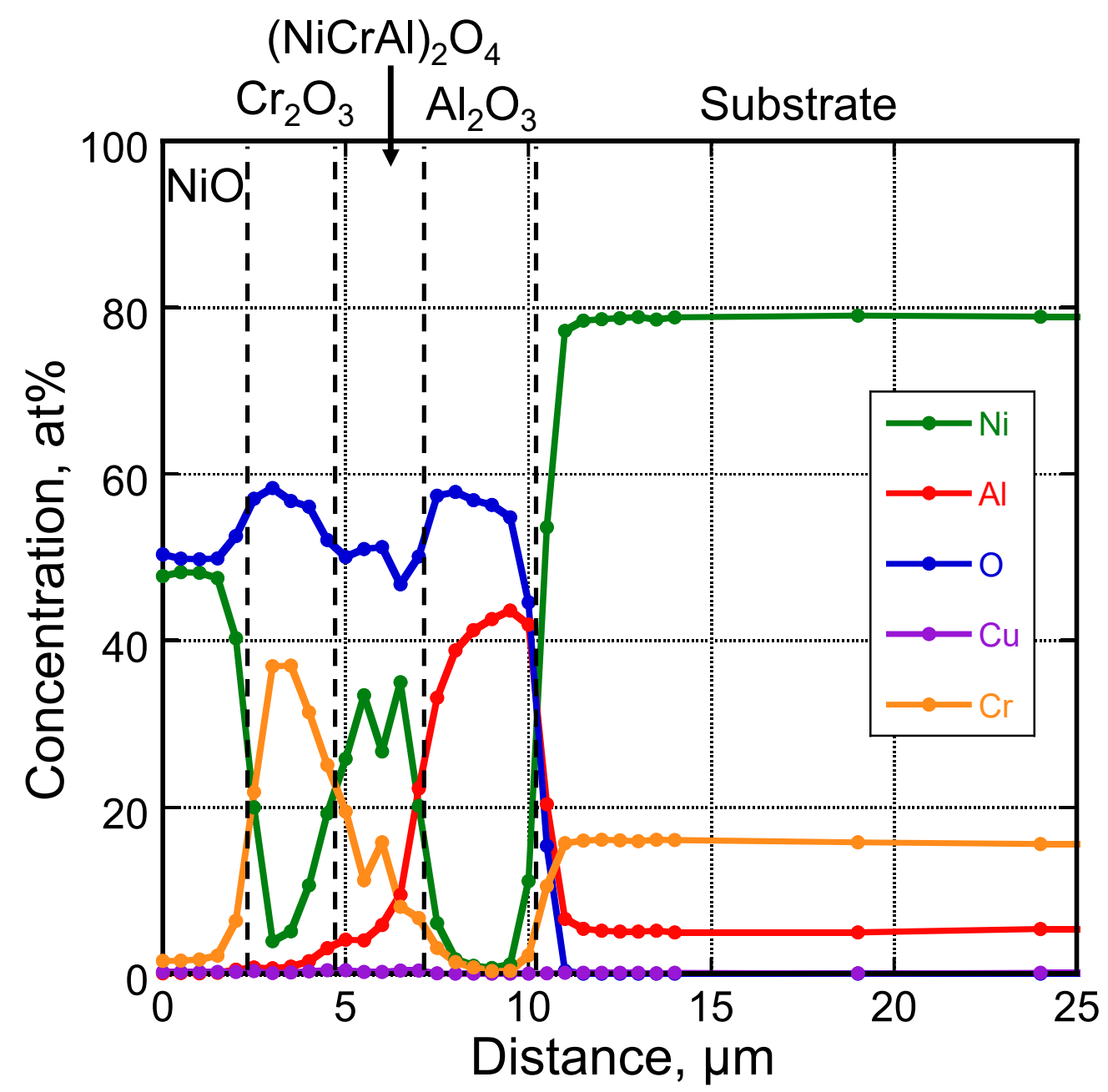

Fig. 9 EPMA concentration profiles of each element of $17 \mathrm{Ni}-17 \mathrm{Cr}-10 \mathrm{Al}$ after $100 \mathrm{~h}$ of oxidation in air at $1000{ }^{\circ} \mathrm{C}$ 
(a)
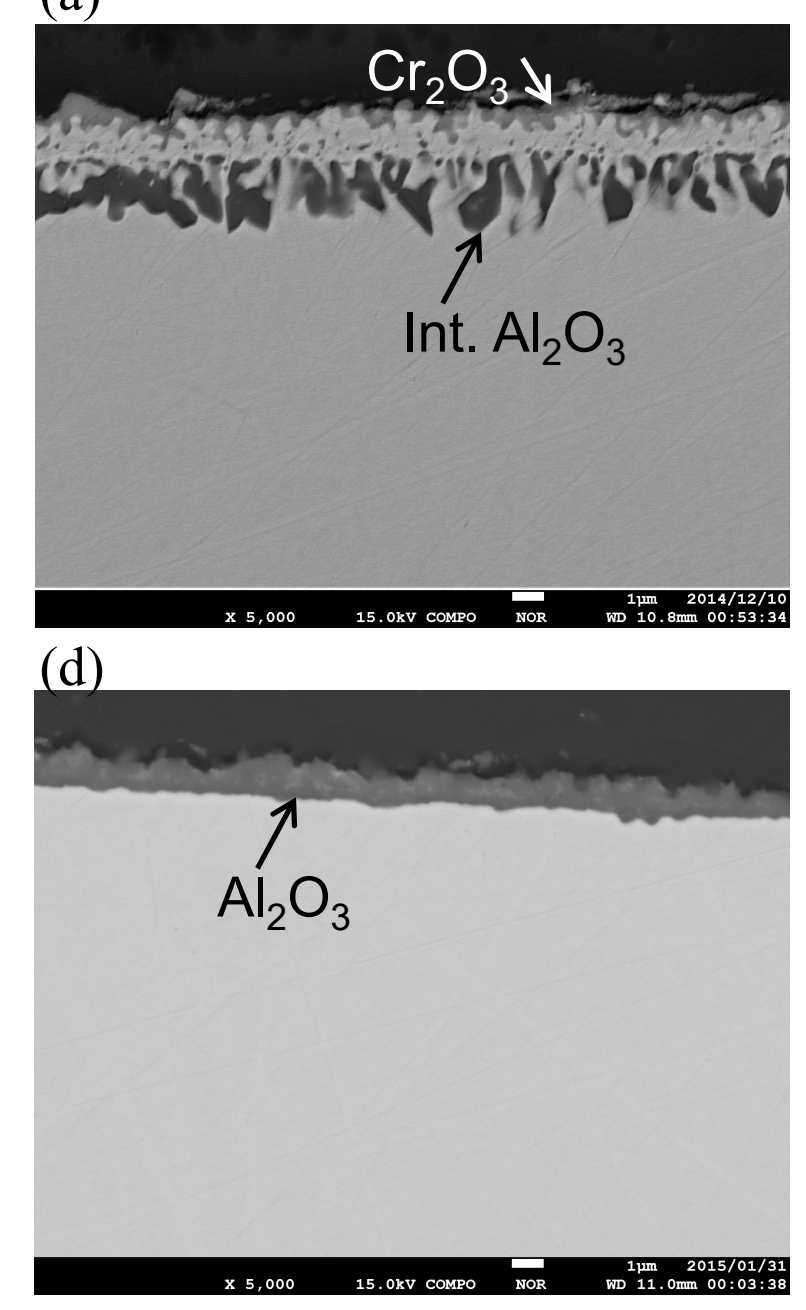

(b)

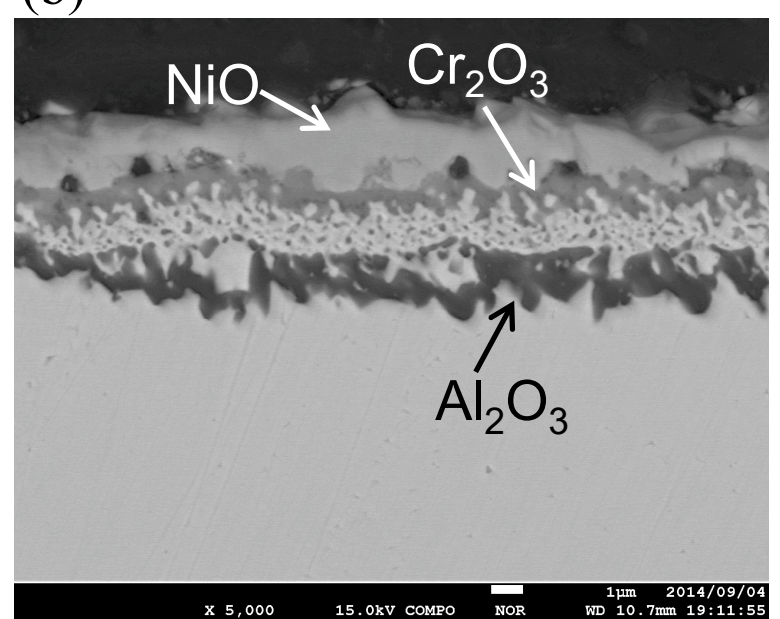

(c)

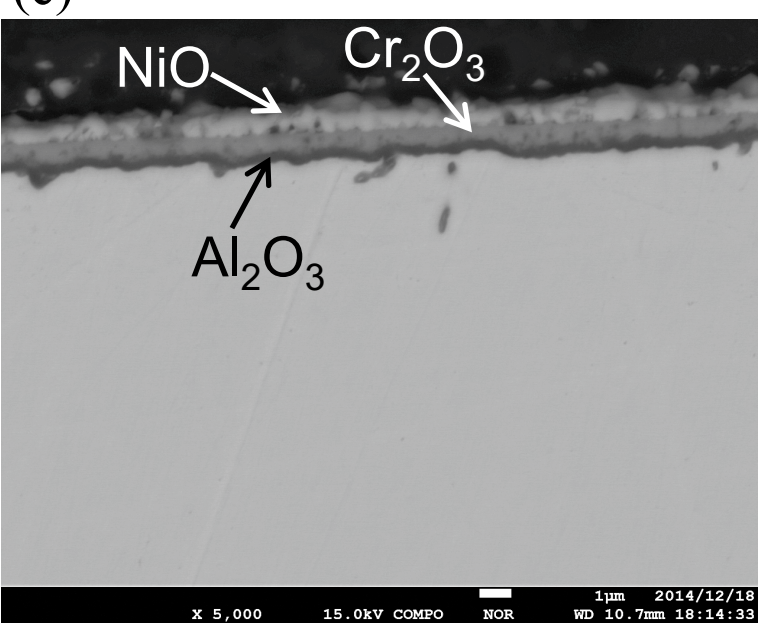

x 5,000

Fig. 10 Cross-sections of oxide scale formed on (a) Ni-17Cr-10Al, with (b) $5 \mathrm{Cu}$, (c) $10 \mathrm{Cu}$, and (d) $15 \mathrm{Cu}$ alloys after $4 \mathrm{~h}$ of oxidation in air at $1000^{\circ} \mathrm{C}$ 


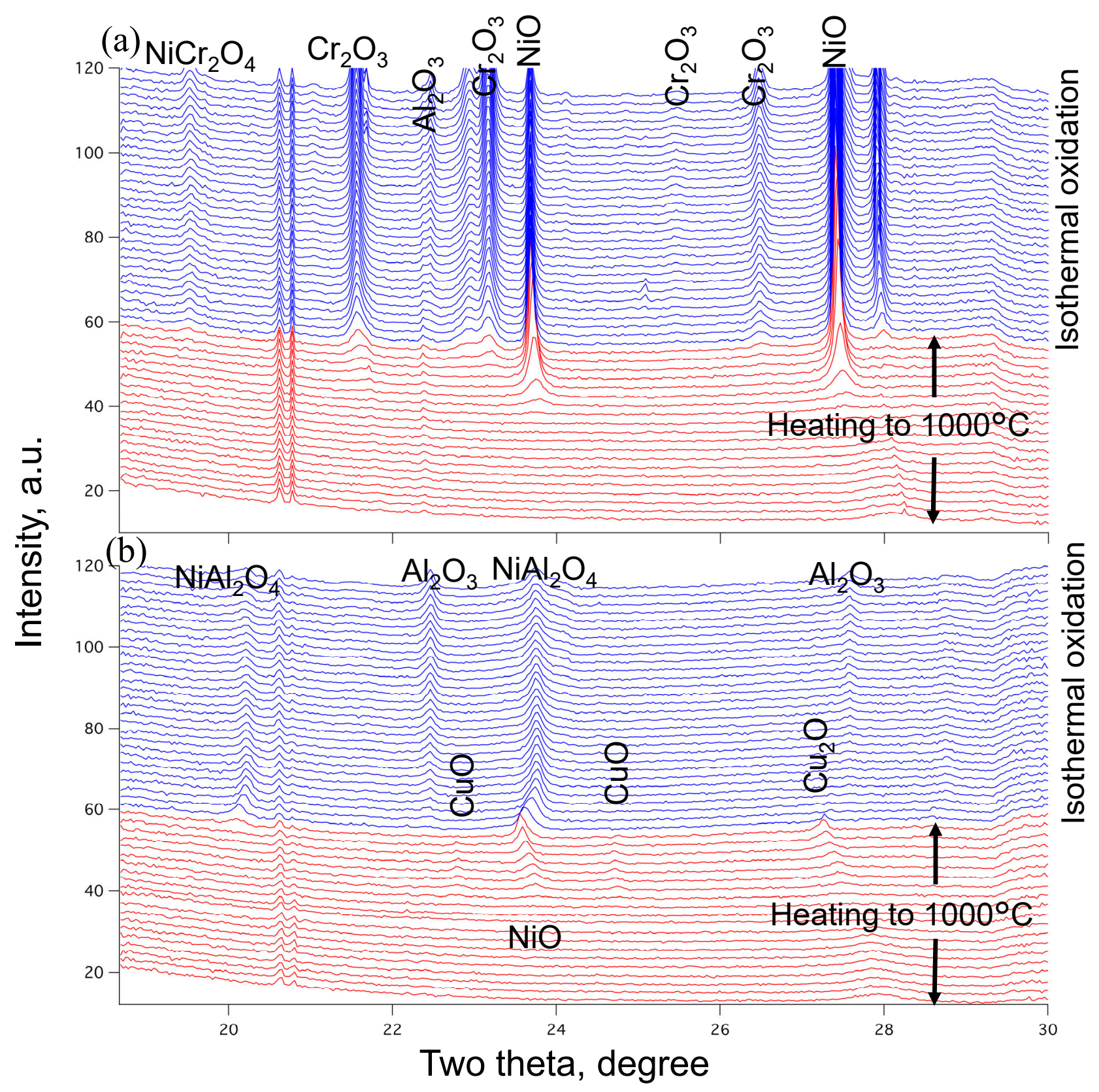

Fig. 11 In-situ HT-XRD patterns of (a)Ni-17Cr-10Al and (b)Ni-17Cr-10Al-15Cu alloys during heating followed by isothermal oxidation in air at $1000^{\circ} \mathrm{C}$ 


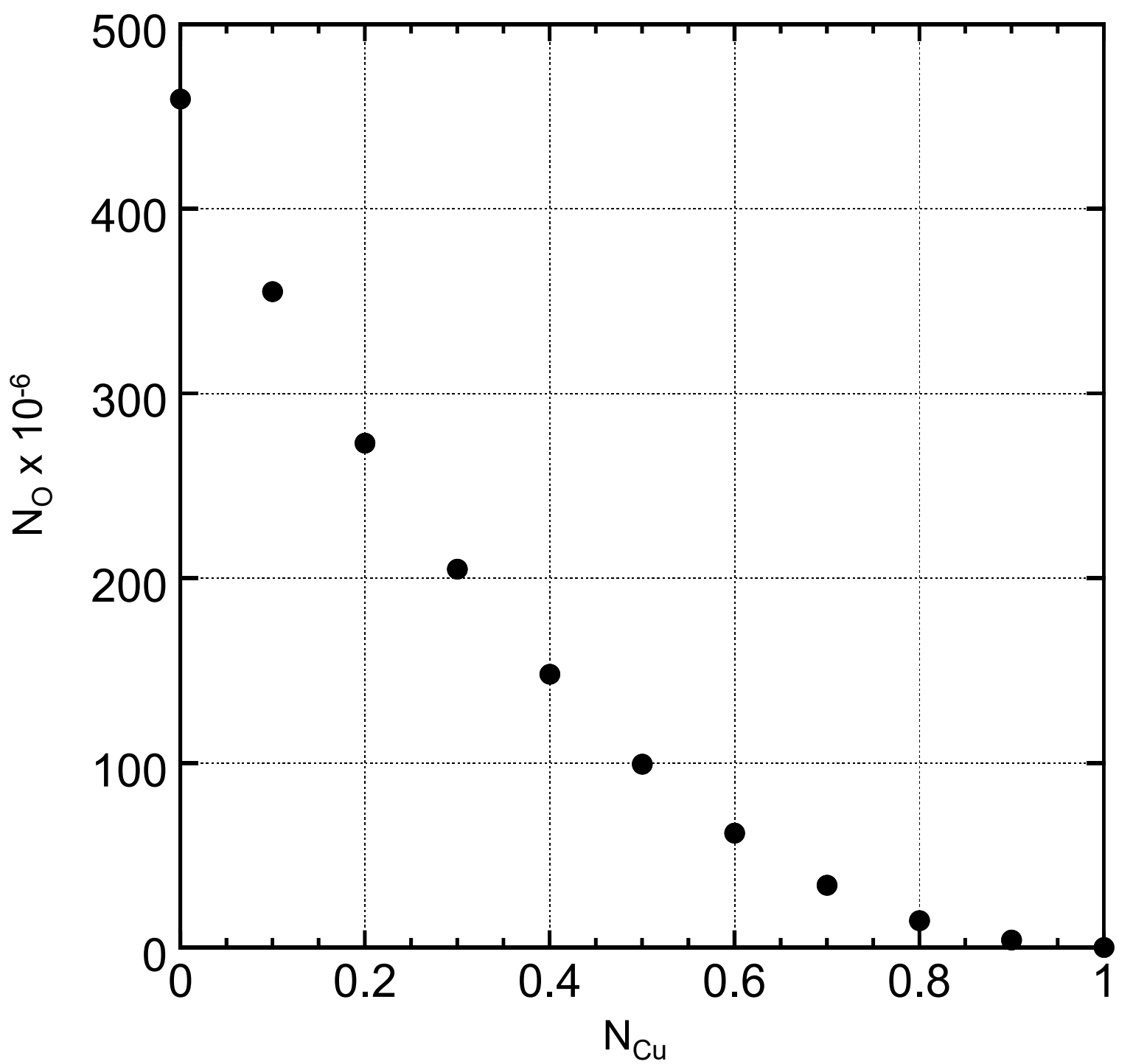

Fig. 12 Effect of $\mathrm{Cu}$ on the oxygen solubility in $\mathrm{Ni}-\mathrm{Cu}$ system at $1000{ }^{\circ} \mathrm{C}$ 


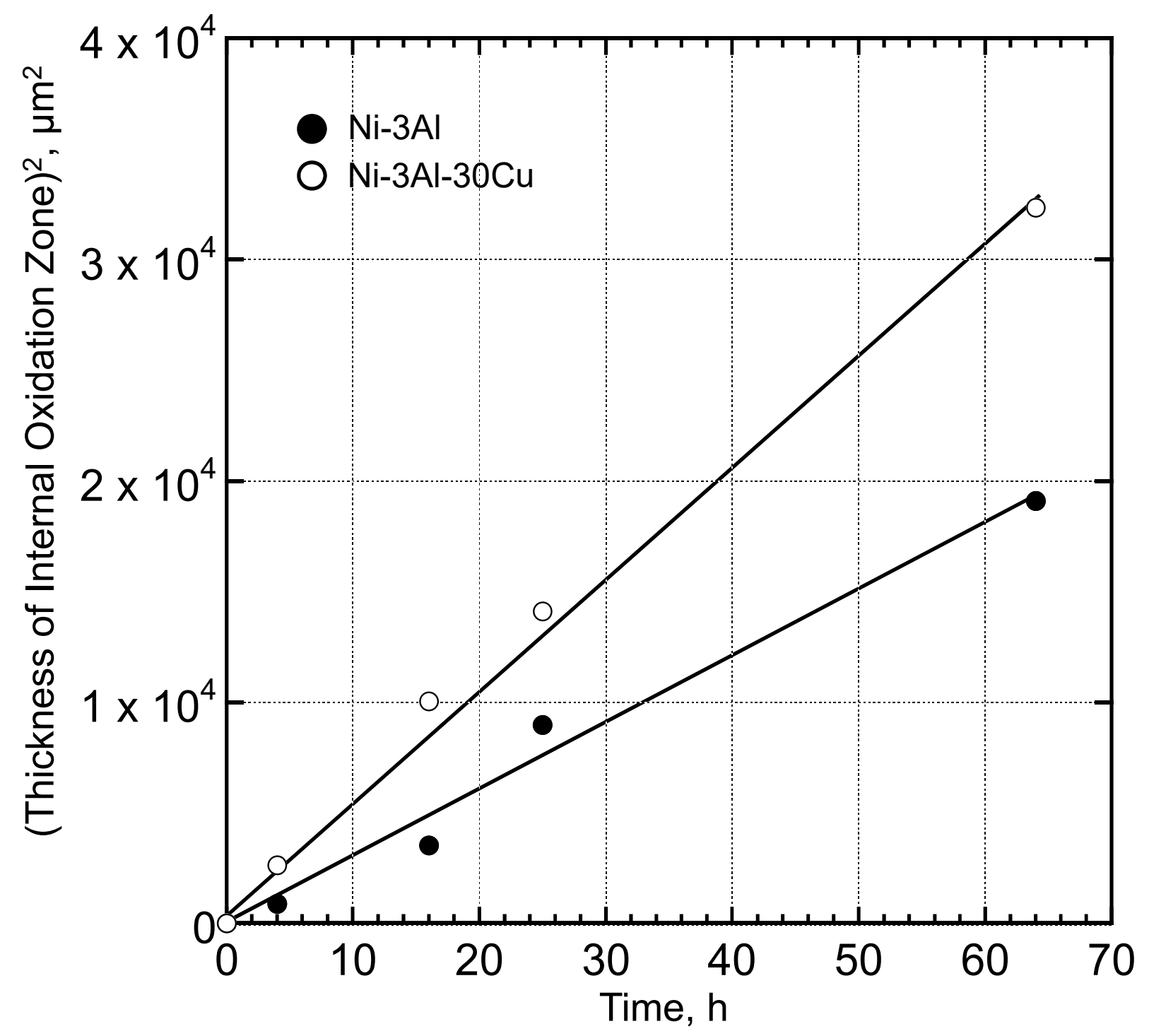

Fig. 13 Internal oxidation kinetics of $\mathrm{Ni}-3 \mathrm{Al}$ and $\mathrm{Ni}-3 \mathrm{Al}-30 \mathrm{Cu}$ at $1000^{\circ} \mathrm{C}$ in $\mathrm{Ni} / \mathrm{NiO}$ mixture 
(a)

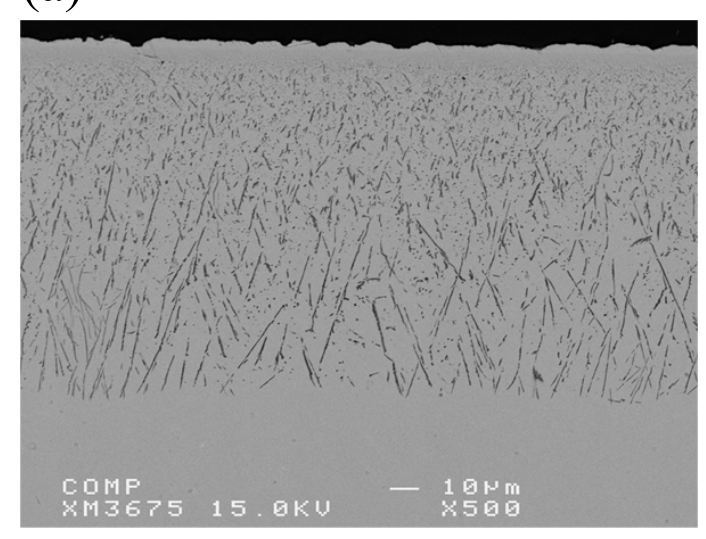

(b)

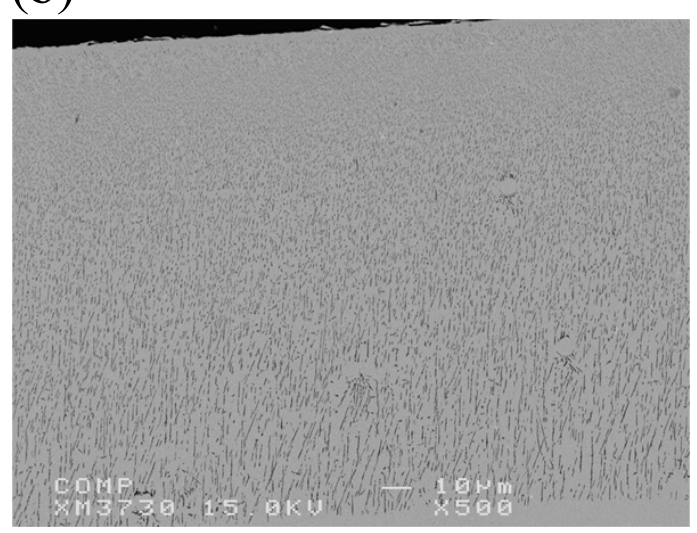

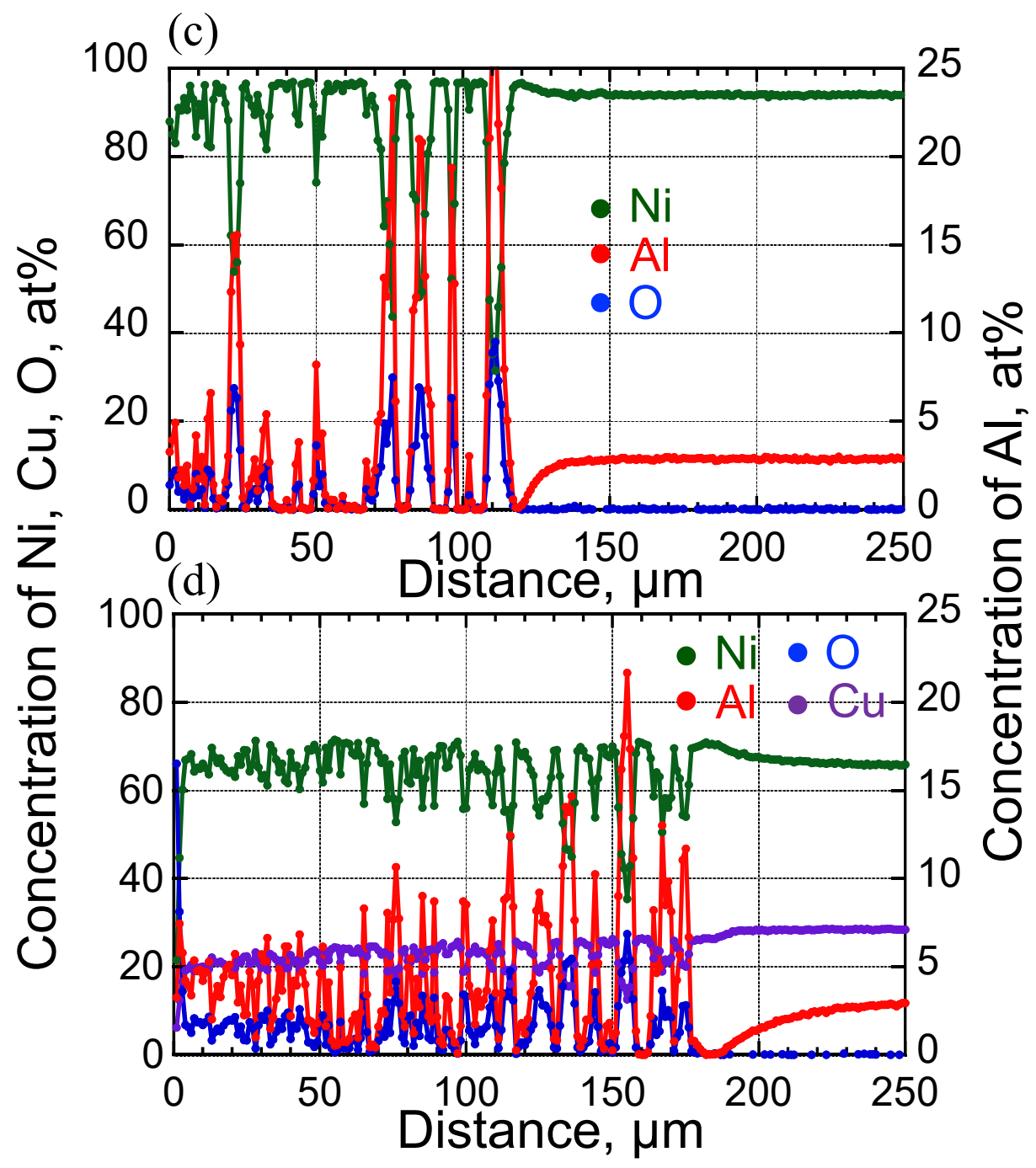

Fig. 14 Cross-sections of (a)Ni-3Al and (b)Ni-3Al-30Cu after internal oxidation for $64 \mathrm{~h}$ at $1000^{\circ} \mathrm{C}$.

(c) and (d) are concentration profiles of each element of (a) and (b), respectively. 


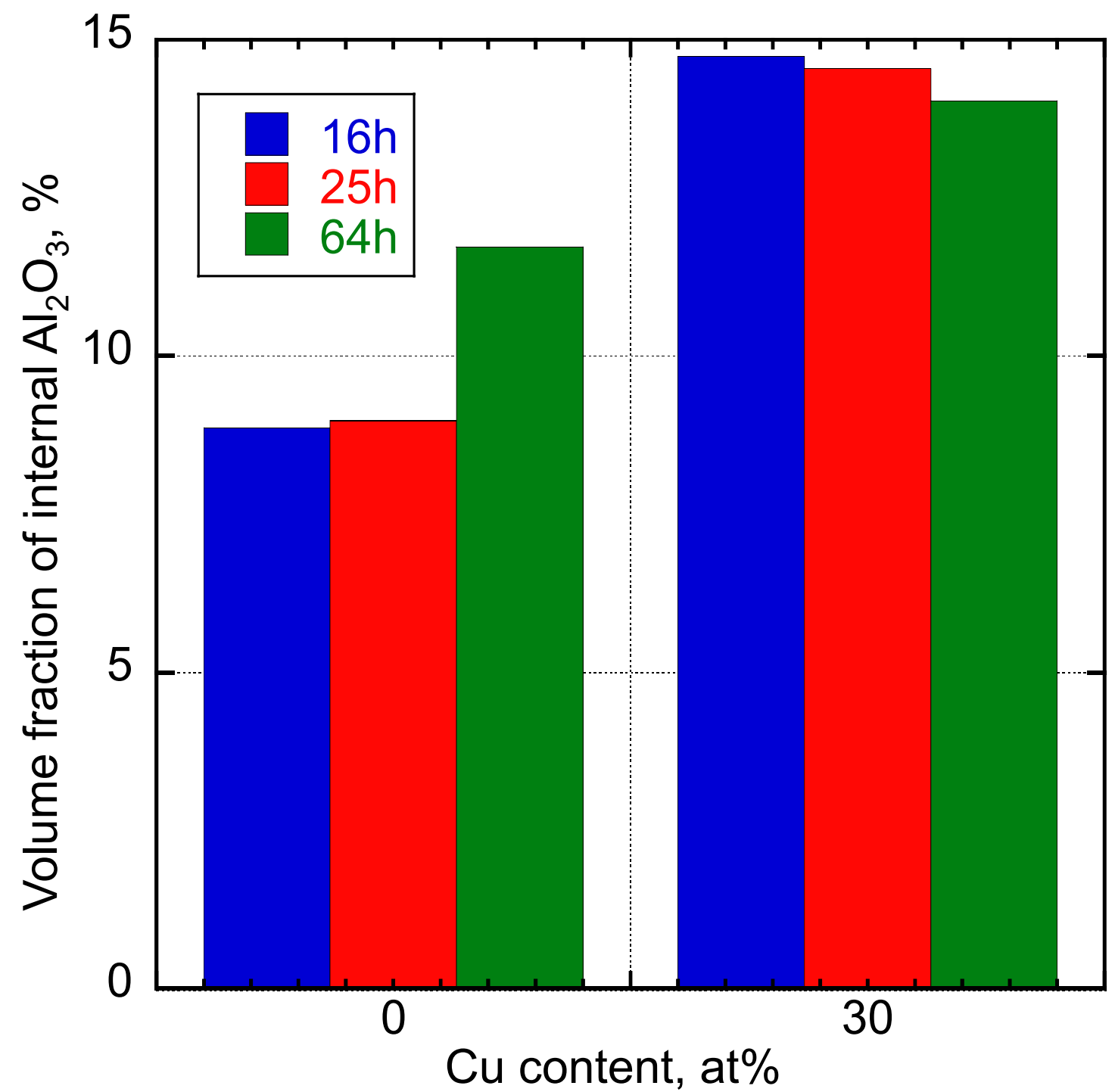

Fig. 15 Volume fraction of internal $\mathrm{Al}_{2} \mathrm{O}_{3}$ precipitates formed in $\mathrm{Ni}-3 \mathrm{Al}$ and $\mathrm{Ni}-3 \mathrm{Al}-30 \mathrm{Cu}$ alloys 
(a)

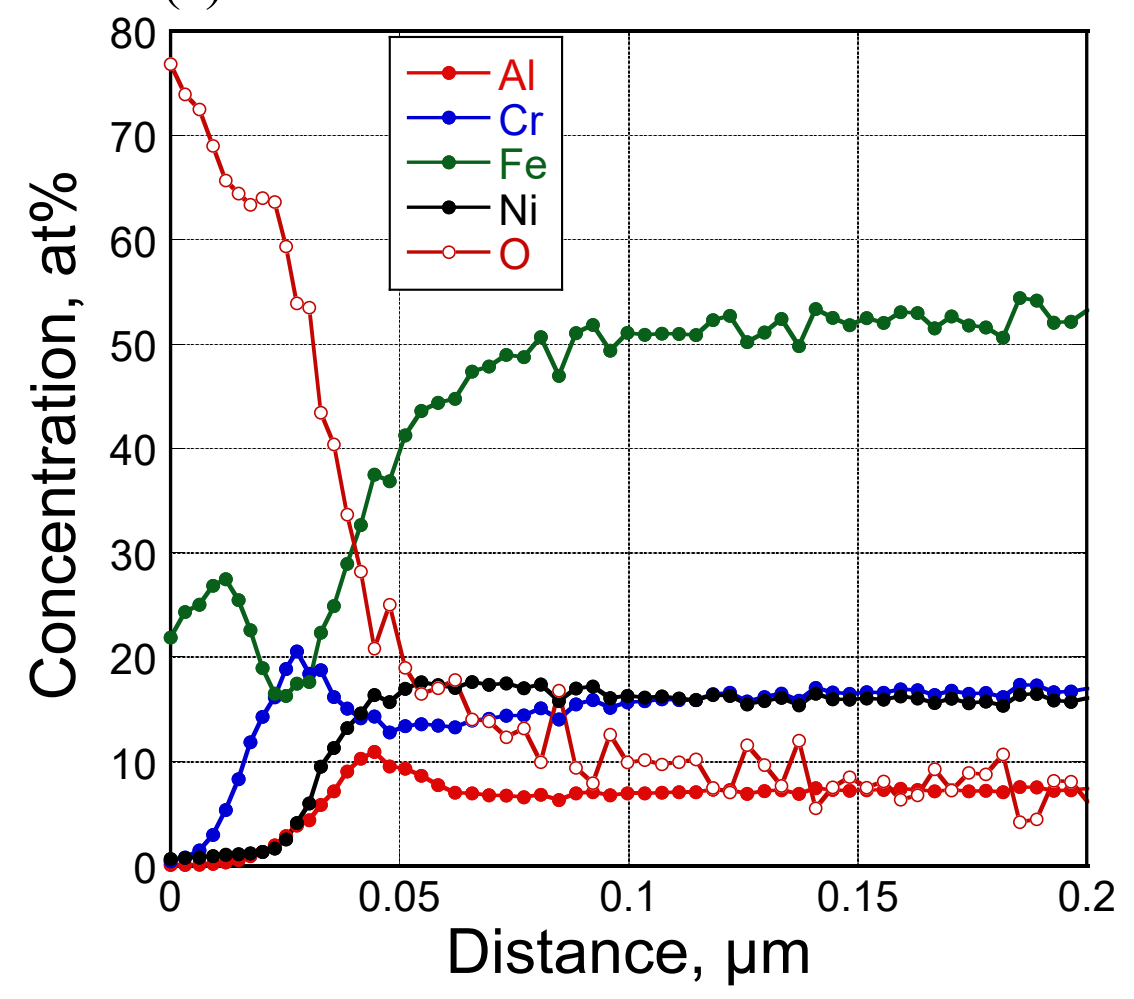

(b)

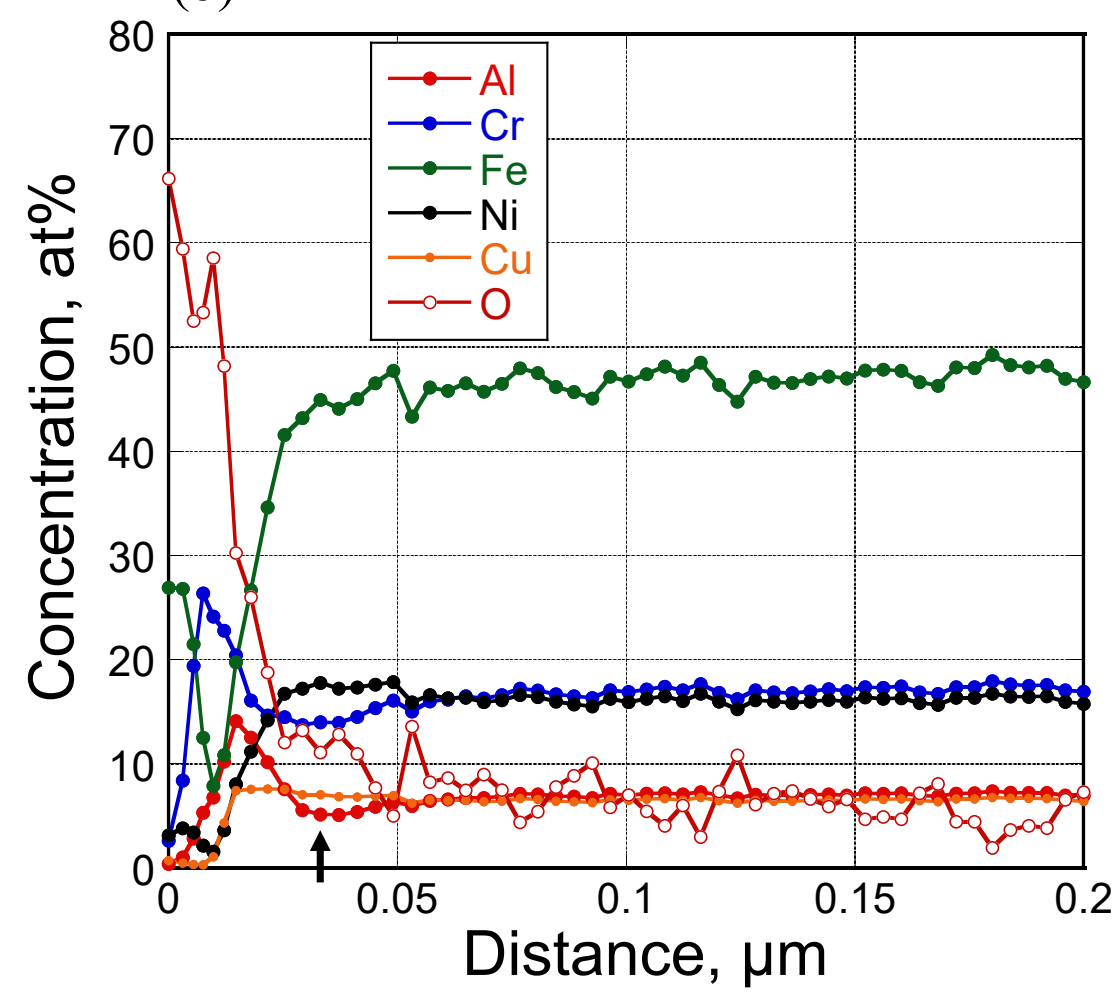

